\title{
Are Overconfident CEOs Better Innovators?
}

\author{
David A. Hirshleifer \\ The Paul Merage School of Business \\ University of California, Irvine \\ Angie Low \\ Nanyang School of Business \\ Nanyang Technological University \\ Siew Hong Teoh \\ The Paul Merage School of Business \\ University of California, Irvine
}

\section{Revised October 2011}

Previous empirical work on adverse consequences of CEO overconfidence raises the question of why firms would hire overconfident managers. Theoretical research suggests a reason, that overconfidence can sometimes benefit shareholders by increasing investment in risky projects. Using options- and press-based proxies for CEO overconfidence, we find that over the 19932003 period, firms with overconfident CEOs have greater return volatility, invest more in innovation, obtain more patents and patent citations, and achieve greater innovative success for given research and development (R\&D) expenditure. Overconfident managers only achieve greater innovation than non-overconfident managers in innovative industries. Our findings suggest that overconfidence may help CEOs exploit innovative growth opportunities.

We thank the editor (Cam Harvey), the associate editor, and two anonymous referees, Sanaz Aghazadeh, Robert Bloomfield, SuJung Choi, Peng-Chia Chiu, Major Coleman, Shane Dikolli, Lucile Faurel, Xuan Huang, Fei Kang, Kevin Koh, Brent Lao, Richard Mergenthaler, Alex Nekrasov, Mort Pincus, Devin Shanthikumar, and participants in the Merage School of Business, UC Irvine Workshop in Psychology and Capital Markets, the brown bag workshop at Nanyang Business School, Nanyang Technical University, and "The Intersection of Economics and Psychology in Accounting Research Conference" at the McCombs School of Business, University of Texas at Austin for very helpful comments, and Peng-Chia Chiu and Xuan Huang for excellent research assistance. 


\section{Introduction}

Steve Jobs, former CEO of Apple Computers, was ranked by Business Week as one of the greatest innovators of the last 75 years in a 2004 article — written before Apple's introduction of the path-breaking iPhone and iPad—-because "More than anyone else, Apple's co-founder has brought digital technology to the masses." Jobs is almost as famous for his self-confidence. According to the same article "He got his first job at 12 after calling Hewlett-Packard Co. ... President Bill Hewlett and landing an internship." After prodigious early success as cofounder of Apple Computers, “Jobs' cocky attitude and the lack of management skills contributed to Apple's problems. He never bothered to develop budgets..." According to an article in Fortune, "Jobs likes to make his own rules, whether the topic is computers, stock options, or even pancreatic cancer. The same traits that make him a great CEO drive him to put his company, and his investors, at risk."

Is this combination of visionary innovation and extraordinary overconfidence a coincidence? We examine here a different possibility - that for CEOs, the two go hand in hand.

A recent literature in corporate finance examines how the psychological biases or characteristics of managers affect firms' decisions (see, e.g., Bertrand and Schoar 2003, Baker, Xin, and Wurgler 2009). Our focus is on overconfidence, the tendency of individuals to think they are better than they really are on relevant characteristics, such as ability, judgment, or prospects for successful life outcomes (the last item sometimes called 'optimism'). Theoretical research has analyzed why overconfidence exists (Benabou and Tirole 2002, Van den Steen 2004); psychological and other research indicates that people, including experts, tend to be

\footnotetext{
${ }^{1}$ See "Steve Jobs: He Thinks Different," BusinessWeek November 1, 2004, and Koontz and Weihrich (2007, p. 331). According to Fortune, "Jobs ...oozes smug superiority, ... No CEO is more willful, or more brazen, at making his own rules, in ways both good and bad. And no CEO is more personally identified with — and controlling of - the day-to-day affairs of his business." ("The Trouble with Steve Jobs," Fortune, March 5, 2008).
} 
overconfident along a variety of dimensions, but that there is substantial and persistent individual variation in the degree of confidence (see, e.g., Oskamp 1965, Weinstein 1980, Wagenaar and Keren 1986, Brenner et al. 1996, and Puri and Robinson 2007).

Overconfident individuals will tend to overestimate the net discounted expected payoffs from uncertain endeavors, either because of the general tendency to expect good outcomes, or because they overestimate their own efficacy in bringing about success. Furthermore, people tend to be more overconfident about their performance on hard than easy tasks (Griffin and Tversky 1992). So we expect relatively overconfident CEOs to be especially enthusiastic about risky, challenging, and talent- and vision-sensitive enterprises.

Innovative projects — which apply new business methods, develop new technologies, or offer new products or services — are risky and challenging. It is for such undertakings that we expect managerial overconfidence to be potentially important. Reinforcing this conclusion, the outcomes of innovative projects take a long time to resolve; overconfidence tends to be more severe in settings with ambiguous and deferred feedback (Einhorn 1980). Furthermore, adopting innovative projects may be viewed as indicative of superior managerial 'vision.' So innovative projects are likely to appeal to self-aggrandizing managers.

We therefore hypothesize that (even after including standard firm-level controls and industry and year fixed effects) firms with overconfident managers accept greater risk, invest more heavily in innovative projects, and achieve greater innovation. ${ }^{2}$ The effect of overconfidence on project selection could come from either overestimation of expected cash flows or underestimation of risk.

\footnotetext{
${ }^{2}$ Some studies fail to find evidence of overconfidence in certain contexts (see, e.g., Gigerenzer, Hoffrage, and Kleinbolting 1991 versus Griffin and Tversky 1992). Although there are exceptions, the preponderance of evidence supports a general tendency toward overconfidence in various manifestations (see e.g., DeBondt and Thaler 1995, Rabin 1998). However, it is not crucial for our purposes whether CEOs are, on average, overconfident. Our tests rely upon substantial differences in the degree of confidence across managers.
} 
Whether overconfident CEOs will be better innovators after controlling for the level of spending on research and development (R\&D) is less clear. On the one hand, overconfident managers who pursue innovation aggressively may undertake projects with low expected payoff. On the other hand, rational managers may, from the viewpoint of shareholders, excessively prefer the ' $\mathrm{D}$ ' in $\mathrm{R} \& \mathrm{D}$ - fairly reliable projects rather than risky but more promising innovative ones. Overconfident managers can potentially achieve higher average innovative productivity by accepting good but risky projects. This benefit of managerial overconfidence is reflected in recent theoretical models (Goel and Thakor 2008, Gervais, Heaton, and Odean 2011). So we do not hypothesize the direction of the effect of overconfidence on the effectiveness of the CEO in generating innovation for given $R \& D$ expenditure.

The biggest puzzle raised by existing research on managerial beliefs and corporate policy is that firms often employ overconfident managers, and give them leeway to follow their beliefs in making major investment and financing decisions (Malmendier and Tate 2005a, 2005b, 2008 and Ben-David, Graham, and Harvey 2010). This is counterintuitive, as we would normally view unbiased beliefs as preferable. Furthermore, Graham, Harvey, and Puri (2010) provide evidence of a matching of growth firms with more confident managers (as proxied by height). This puts the most confident managers into those firms where overconfidence can radically influence strategy, investment choices, and survival. By measuring ex post success, we suggest a possible solution to this overconfident manager puzzle: that overconfident managers are better innovators.

To test our hypotheses, we use alternative proxies for managerial overconfidence based upon options exercise behavior or press coverage. The options exercise measure (Malmendier and Tate 2005a) is based on the idea that a manager who chooses to be exposed to the firm's idiosyncratic risk is likely to be confident about the firm's prospects. Under this approach, a 
CEO who voluntarily retains stock options after the vesting period in which exercise becomes permissible is viewed as overconfident. ${ }^{3}$ Our second measure of overconfidence is based upon the portrayal of the CEO in the news media, as developed by Malmendier and Tate (2005b, 2008). This is based on counts of words relating to overconfidence or its opposite in proximity to the company name and the keyword 'CEO.'

We measure the firm's innovation-related investment by the level of R\&D expenditure. Our first measure of innovative output and $R \& D$ success is the number of patents applied for during the year from the US Patents and Trademarks Office. Patents differ greatly in their importance, so following Trajtenberg (1990), our second measure of innovative output is total citation count. This is the total number of citations subsequently received by the patents applied for during the year, where citations are made by other newer patents.

We find that over the 1993-2003 period, firms with overconfident CEOs have higher stock return volatility, consistent with their undertaking riskier projects. Overconfident CEOs invest more heavily in $\mathrm{R} \& \mathrm{D}$, and achieve a greater total quantity of innovation as measured by patent and citation counts. Greater innovative output is not just a result of greater resource input; overconfident CEOs achieve greater innovative success even after controlling for the level of R\&D expenditure. Patenting may be less relevant for certain industries, either because they are less innovative, or because in these industries innovation does not result in patents. We find that overconfident managers only achieve greater total patents and citations than non-overconfident managers in industries where innovation is important. We also provide evidence that our results are not due to overconfident CEOs having private information about future profits or that they are just more risk-tolerant.

\footnotetext{
${ }^{3}$ Malmendier and Tate (2005a, 2008) develop measures of CEO overconfidence based on their options exercising behavior and insider net stock purchases. Billet and Qian (2008), Liu and Taffler (2008), and Campbell et al. (2011) also adopt this measurement approach.
} 
The greater innovative output for given R\&D input achieved by overconfident CEOs does not necessarily translate into higher firm value. Hall, Jaffe, and Trajtenberg (2005) show that, on average, patent citations are positively correlated with firm value, but overconfident CEOs could be overpaying to achieve increased citation counts (possibly using resources other than R\&D expenditures), reducing firm value. A possible way to address this issue is to regress firm value on CEO overconfidence or the innovation that results from it. However, such a test is subject to endogeneity problems. Instead, using an instrument for exogenous growth opportunities, we examine a more limited question: are overconfident CEOs better at translating external growth opportunities into firm value? We find that the answer is yes, and that this relation is especially strong among industries where innovation is important.

Throughout, we find that the effect of overconfidence on innovation is mainly found among innovative industries. Since innovative industries should contain more good risky growth opportunities, our results are consistent with models such as those of Goel and Thakor (2008) and Gervais, Heaton, and Odean (2011) that imply high benefits to overconfidence when such opportunities are present.

Recent work has identified other important effects of managerial overconfidence on firm investments. Malmendier and Tate (2005a) propose that overconfident managers are optimistic about investment opportunities, but overestimate the value of their firms' equity and therefore the cost of external financing. This implies that firms with overconfident CEOs will have greater investment-cash flow sensitivity. Their evidence is consistent with this prediction. Ben-David, Graham, and Harvey (2010) document that firms whose CFOs are overconfident in the sense of having miscalibrated beliefs undertake greater capital expenditures. Our paper differs from these contributions in focusing on innovative investments, for which we would expect overconfidence 
to be especially important; and on the effectiveness of this investment as measured by patent and citation counts for a given level of innovative investment.

With regard to other firm behaviors, Hribar and Yang (2011) find that overconfident managers are more likely to issue optimistically biased forecasts. Schrand and Zechman (2010) find that overconfidence is associated with a greater likelihood of earnings management and financial fraud. Graham, Harvey, and Puri (2010) document the relation of managerial traits, including confidence, to a variety of corporate policies. Malmendier, Tate, and Yan (2011) find that overconfident managers are less likely to use external finance, and issue less equity. Malmendier and Tate (2008) find that CEO overconfidence is associated with making acquisitions, and with more negative market reactions to acquisition announcement. Most of these findings add to the puzzle of why firms are willing to hire overconfident managers. ${ }^{4}$

\section{Data and Descriptive Statistics}

\subsection{The Data}

We use several databases to construct our sample. The Standard and Poor's Execucomp database provides information on the CEOs and their compensation, and we use the data on option compensation to construct one of our two measures of CEO overconfidence. The second overconfidence measure relies on keyword searches of the text of press articles in Factiva. All accounting data are from Compustat and stock returns are from CRSP. Patent-related data are from the 2006 edition of the NBER patent database.

\footnotetext{
${ }^{4}$ After developing this paper, we became aware of a recent paper that examines the relation between managerial overconfidence and innovation (Galasso and Simcoe 2010). Our papers differ in several ways. We examine how overconfidence affects risk-taking as well as innovation, and we show that the effects of managerial overconfidence come solely from innovative industries. We also examine the effects of overconfidence on firm performance. To ensure the robustness of our conclusions, we use the press-based measure of overconfidence as well as the optionsbased measure. Finally, our time period and sample size differ substantially. Our time period, 1993-2003, encompasses the millennial high-tech boom, and overlaps little with their 1980-94 sample. Our sample is also much larger, as it is drawn from the top 1,500 firms covered by Execucomp. It consists of 1,771 firms and 9,807 firm-year observations; their sample covers 290 firms and 3,648 firm-years.
} 
The sample consists of firms in the intersection of Execucomp, Compustat, CRSP, and the patent database. All Execucomp firms that operate in the same 4-digit SIC industries as the firms in the patent database are included; the sample is therefore not limited to firms with patents. Firm-years with missing data on any of the control variables and dependent variables are deleted. We further require that there be information on at least one of the CEO overconfidence measures. Since these measures are lagged by one year, we require that the CEO be the same one in the prior year to ensure that we observe the characteristics of the CEO who is in place at the time that innovation is being measured. Financial firms and utilities are excluded. The final sample consists of 2,577 CEOs from 9,807 firm-year observations between 1993 and 2003. 8,939 firmyears have information on the options-based measure, while 7,762 firm-years have information on the press-based measure of overconfidence.

To test our hypothesis that overconfident CEOs undertake riskier projects, as dependent variable we use the standard deviation of daily stock returns during the fiscal year. We measure innovation using $R \& D$ expenditures and patenting activities which we describe in detail in the next subsection. The measurement of CEO overconfidence and the associated control variables are also discussed below. A detailed summary of variable definitions is provided in Appendix A.

\subsubsection{Measuring Innovation}

We measure resource input into innovation with R\&D scaled by book assets. Firm-years with missing R\&D information are assigned a zero R\&D value. ${ }^{5}$ Our output-oriented measures of innovation are based upon patent counts and patent citations.

Data for patent counts and patent citations are constructed using the 2006 edition of the NBER patent database (Hall, Jaffe, and Trajtenberg 2001). This covers over 3.2 million patent

\footnotetext{
${ }^{5}$ Our results are robust to deleting firm-years with missing R\&D instead. The major robustness checks in the paper that are not tabulated in the main text are contained in the online appendix.
} 
grants and 23.6 million patent citations from 1976 to 2006 . Our second measure of innovation is the number of patent applications by a firm during the year.

Patents are included in the database only if they are eventually granted. Furthermore, there is on average a two-year lag between patent application and patent grant. Since the latest year in the database is 2006, patents applied for in 2004 and 2005 may not appear in the database. As suggested by Hall, Jaffe, and Trajtenberg (2001), we end our sample period in 2003 and include year fixed effects in our regressions to address potential time truncation issues.

Simple patent counts capture innovation success imperfectly (see e.g., Griliches, Pakes, and Hall 1987) as patent innovations vary widely in their technological and economic importance. A measure of the importance of a patent is its citation count. Patents continue to receive citations from other patents for many years subsequent to granting. Trajtenberg (1990) concludes that citations are related to the social value created by the innovation; Hall, Jaffe, and Trajtenberg (2005) show that forward citations are related to firm value as measured by Tobin's $Q$. Therefore, our third measure of innovation is the total number of citations ultimately received by the patents applied for during the given year; as such it takes into account both the number of patents and the number of citations per patent. (Results are similar when we exclude selfcitations.)

Survivorship bias is minimal in the patent database. ${ }^{6}$ However, owing to the finite length of the sample, citations suffer from a time truncation bias. Since citations are received for many years after a patent is created, patents created near the ending year of the sample have less time to accumulate citations. To address this, we follow the recommendations of Hall, Jaffe, and

\footnotetext{
${ }^{6}$ An ultimately successful patent application is counted and attributed to the applying firm at the time of application even if the firm is later acquired or goes bankrupt. Furthermore, citations are specific to a patent and not a firm. Therefore, a patent that belongs to a bankrupt firm can continue to receive citations in the database for many years after the firm goes out of existence.
} 
Trajtenberg $(2001,2005)$ and adjust the citation count of each patent in two different ways. For the first adjustment, each patent's citation count is multiplied by the weighting index from Hall, Jaffe, and Trajtenberg $(2001,2005)$, also found in the NBER patent database. ${ }^{7}$ Qcitation count is the sum of the adjusted patent citations across all patents applied during each firm-year.

For the second adjustment, each patent's citation count is scaled by the average citation count of all patents in the same technology class and same year. TTcitation count is the sum of adjusted citation count across all patents applied by the firm during the year. ${ }^{8}$

\subsubsection{Options-based Measure of CEO Overconfidence}

The options-based overconfidence measure is based on the premise that it is typically optimal for risk-averse, undiversified executives to exercise their own-firm stock options early if the option is sufficiently in-the-money (Hall and Murphy 2002). Following Malmendier and Tate (2005a, 2008), Confident CEO (Options) takes on the value one once a CEO postpones the exercise of vested options that are at least $67 \%$ in the money, and is zero otherwise. Once a CEO is identified as overconfident by this measure, she remains so for the rest of the sample period.

This treatment is consistent with the notion that overconfidence is a persistent trait.

As we do not have detailed data on the CEO's options holdings and exercise prices for each option grant, we follow Campbell et al. (2011) in calculating an average moneyness of the CEO's option portfolio for each year. First, for each CEO-year, we calculate the average realizable value per option by dividing the total realizable value of the options by the number of options held by the CEO. The strike price is calculated as the fiscal year end stock price minus

\footnotetext{
${ }^{7}$ The weighting index is created using a quasi-structural approach where the shape of the citation-lag distribution is econometrically estimated.

${ }^{8}$ An advantage of TTcitation count is that it takes into account the differing propensity for patents in different technology class to cite other patents. However, such an adjustment assumes that any average difference in citation rates across technology fields is an artifact of different citation habits across fields rather than an actual difference in the value of the knowledge created. Therefore, we also show results with Qcitation count.
} 
the average realizable value. The average moneyness of the options is then calculated as the stock price divided by the estimated strike price minus 1 . As we are only interested in options that the CEO can exercise, we include only the vested options held by the CEO.

Malmendier and Tate (2005a, 2008) classify a CEO who failed to exercise a $67 \%$ in-themoney option and who has five years of remaining duration as overconfident. In contrast, our overconfidence measure is based solely on non-exercise when average moneyness is high. Using this measure with the Execucomp sample allows us to include more firms and to cover a more recent period that includes the millennial high-tech boom. Although this measure is less precise, Malmendier, Tate, and Yan (2011) show that it works well after controlling for past stock return performance. Furthermore, Campbell et al. (2011) has shown that this measure of overconfidence generates results similar to those in Malmendier and Tate (2005a).

\subsubsection{Press-Based Measure of CEO Overconfidence}

Following Malmendier and Tate (2005b, 2008) and Hribar and Yang (2011), we also use a press-based measure of CEO overconfidence. ${ }^{9}$ We search Factiva for articles referring to the CEO in the New York Times, BusinessWeek, Financial Times, the Wall Street Journal, The Economist, Fortune, and Forbes. Specifically, we retrieve all articles using the available unique company code in Factiva and the search keyword 'CEO.' For each CEO and year, we record (1) the total number of articles, (2) the number of articles containing the words 'confident,' 'confidence,' or variants such as overconfidence and over-confident, (3) the number of articles containing the words 'optimistic,' 'optimism,' or variants such as overoptimistic, over-optimism, (4) the number of articles using 'pessimistic,' 'pessimism' or variants such as over-pessimistic,

\footnotetext{
${ }^{9}$ Other approaches to measuring executive overconfidence include surveys and psychometric tests (Ben-David, Graham, and Harvey 2010 and Graham, Harvey, and Puri 2010) and the CEO's prevalence in photographs in the annual report (Schrand and Zechman 2010).
} 
and (5) the number of articles using 'reliable,' 'steady,' 'practical,' 'conservative,' 'frugal,' 'cautious,' or 'gloomy.' Category 5 also contains articles in which 'confident' and 'optimistic' are negated.

For each year, we compare the number of articles that use the 'Confident' terms, i.e., categories 2 and 3, and articles that use the 'Cautious' terms, i.e., categories 4 and 5. We measure CEO overconfidence for each CEO $i$ in year $t$ as

Confident $C E O(\text { Press })_{i t}=\left\{\begin{array}{c}1 \text { if } \sum_{s=1}^{t} a_{i s}>\sum_{s=1}^{t} b_{i s} \\ 0 \text { otherwise, }\end{array}\right.$

where $a_{i s}$ is the number of articles using the 'Confident' terms and $b_{i s}$ is the number of articles using the 'Cautious' terms. We cumulate articles starting from the first year the CEO is in office (for CEOs who assumed office after 1992) or 1992 when we begin our article search and is also the first year of Execucomp data.

Following Malmendier and Tate (2008), we also control for the total number of press mentions over the same period (TotalMention). The press may be biased toward positive stories and this would imply a higher number of mentions as 'confident' or 'optimistic' when there is more attention in the press. In our regression tests, the CEO overconfidence measures are lagged by one period with respect to the dependent variable. Thus, only past articles are used to predict innovation. In one of our robustness checks, we define our press-based confidence measure using only news articles in the past one year; the results are generally similar.

\subsubsection{Other Explanatory Variables}

When explaining patenting activities, following Hall and Ziedonis (2001) we include controls for firm size and capital intensity, where firm size is the natural logarithm of sales. 
Capital intensity is proxied by the natural logarithm of the ratio of net Property, Plant, and Equipment in 2006 dollars to the number of employees. Aghion, Van Reenen, and Zingales (2009) show that innovative activities are affected by institutional holdings, so we include a measure of the percentage of shares held by institutional investors.

Both of our measures of overconfidence may be affected by past stock performance. High returns increase the moneyness of options held by CEOs. So in addition to reflecting overconfidence in the exercise decision of the CEO, our overconfidence measure may reflect stock price performance subsequent to the option grant date. High past returns could also be associated with greater press usage of the word "confident." If good stock performance is also associated with more innovation, our tests may capture a spurious association between measured overconfidence and innovation. We therefore control for the buy-and hold stock return over the fiscal year preceding the measurement of the dependent variable. In additional tests, we verify the robustness of the results to controlling for stock returns over longer periods.

When explaining stock return volatility and R\&D expenditures, we include as control variables firm size, capital intensity, Tobin's Q, sales growth, return on assets (ROA), stock return, book leverage, and cash holdings. All the regressions include year and industry fixed effects, where the industry is defined at the 2-digit SIC level.

We also include controls that take into account CEO tenure and incentives: CEO delta and CEO option holdings vega. Delta is defined as the dollar change in a CEO's stock and option portfolio for a $1 \%$ change in stock price, and measures the CEO's incentives to increase stock price. Vega is the dollar change in a CEO's option holdings for a $1 \%$ change in stock return volatility; it measures the risk-taking incentives generated by the CEO's option holdings. We calculate delta and vega values using the one-year approximation method of Core and Guay 
(2002). The results are robust to controlling for CEO incentives using percentage stock ownership and option holdings instead of delta and vega. All control variables are lagged by one period and winsorized at the $1 \%$ level in both tails.

\subsection{Descriptive Statistics}

Table 1 describes the frequency of overconfident CEOs in our sample. Steve Jobs of Apple Computers turns out to be overconfident in our sample using both measures of overconfidence. The two measures generate very different average frequencies of overconfident CEOs: $61 \%$ with the options-based measure, and $8 \%$ with the press-based measure. However, a CEO-year is more likely to be classified as overconfident by the press-based measure when the CEO-year is overconfident using the options-based measure; out of the CEO-years with nonmissing data on both measures, $6 \%$ of the CEO-years are classified as overconfident by both measures, while only 3\% are classified as overconfident by the press-based measure when the options-based measure indicates otherwise.

The relatively small number of overconfident CEOs under the press-based measure suggests that the press-based measure may be more stringent. If so, those it identifies as overconfident are more likely to actually be overconfident, but the non-overconfident category may contain a relatively high number of misidentified overconfident CEOs.

A manager who is identified as overconfident in any year using the options-based measure remains so throughout the sample period. This mechanically tends to induce an increase in the fraction of overconfident managers through the sample period. This is evident in the earlier part of the sample period. However, owing to increased CEO turnover activity (see e.g., Kaplan and Minton 2008), during the second half of the sample period there is a slight decreasing trend 
in the fraction of overconfident CEOs. Under the press-based measure, a CEO can sometimes change from being confident to non-confident, but the measure is highly persistent. ${ }^{10}$

Table 2 provides descriptive statistics. Panel A classifies the sample according to the options-based confidence measure. Consistent with our hypotheses, more confident managers

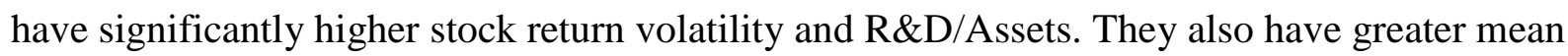
number of patents applied for and total citation count, both raw and adjusted. An overconfident CEO has on average about 9 more patents than a non-overconfident CEO and has about 1.4 to 1.8 times as many citations, depending on the measure of citation. Overconfident CEOs also have significantly higher average adjusted citations per patent.

Panel B classifies the sample according to the press-based measure. As with Panel A, overconfident managers have higher innovation measures. Furthermore, compared to Panel A, the effects of overconfident CEO on patenting activities is even larger, consistent with the pressbased measure being a more stringent proxy for overconfidence. For example, an overconfident CEO has on average 79 patents, while a non-overconfident CEO has only 20; an overconfident CEO has about three times as many citations as the non-confident CEO.

With respect to the controls, in Panel A for options-based overconfidence, overconfident CEOs manage smaller firms, and firms with higher Tobin's Q, greater sales growth, greater performance as measured by ROA and stock return, lower book leverage, lower capital intensity (PPE/emp), greater cash to asset ratio, more institutional holdings, and fewer business segments. Such firms also tend to have lower industry price to earnings ratio.

\footnotetext{
${ }^{10}$ A switch can occur when there is a large increase in the number of articles that use the 'Cautious' terms relative to articles that use the 'Confident' terms. In our sample, given that in period $t$, the CEO is classified as overconfident, she will still be overconfident $92 \%$ of the time in period $t+1,87 \%$ of the time in period $t+2$, and $85 \%$ of the time in period $t+3$.
} 
Overconfident CEOs also tend to have longer tenure and higher delta and vega values.

The last two items make sense, as an overconfident manager who expects to perform well and to take risky projects should be more willing to accept compensation that is more positive sensitive to performance and risk.

For Panel B using the press-based measure, some of these relations are different, probably because the press-based measure of overconfidence is more strongly tilted toward large firms. For example, the sales of firms with overconfident CEOs are on the order of 3-4 times greater than the sales of non-overconfident firms. Given this, it is not surprising that the sales growth rate of overconfident firms is significantly smaller that of non-overconfident firms. We do not view this as indicating that low-growth firms try to hire overconfident managers; this is probably a consequence of the fact that small firms tend to grow more rapidly than large firms.

\section{Overconfidence and Risk-Taking}

We hypothesize that overconfident managers are more willing to undertake risky projects because they expect to succeed in such undertakings. Therefore, we examine the relation between CEO overconfidence and overall firm volatility in Table 3. For each of the options- and press-based overconfidence measures, we use two specifications. Our base specification includes only firm characteristics. In the second specification, we also include manager-related controls, CEO tenure and CEO delta and vega values. For ease of interpretation, all the continuous independent variables are standardized to have mean of zero and standard deviation of one. Standard errors are clustered at the firm level.

We measure stock return volatility as the standard deviation of daily stock returns, expressed in percentage terms. Models (1)-(2) use the options-based measure of overconfidence, and models (3)-(4) use the press-based measure. Following Malmendier and Tate (2008), in all 
the press-based tests, we additionally control for TotalMention, which measures the frequency with which the manager is referred to in the press.

In all the tests, CEO overconfidence is associated with higher subsequent realized stock return volatility. The coefficient in the base model (1) shows that having an overconfident CEO significantly increases daily return volatility by 6 basis point which is about $1 \%$ on an annualized basis. The economic and statistical significance of the coefficient in model (2) is higher. As a benchmark for comparison, we examine the effect of size. The table shows coefficients where the independent variables are scaled by their standard deviations. The coefficient on the unscaled $\log$ (sales) in model (1) is -0.223 , which indicates that a doubling of sales decreases volatility by $\log (2) *(0.223)=0.2 \%$ per day or $2.5 \%$ per year. So the absolute value of the effect of overconfidence on volatility is smaller than, but of the same order of magnitude as, the effect of doubling firm size.

Using the press-based measure of overconfidence, the effect on volatility is larger. In models (3) and (4), the coefficients on Confident CEO (Press) are 0.199 and 0.203, respectively $(p<0.01)$. Model $(3)$ shows that having an overconfident CEO is associated with daily return volatility being higher by close to 20 basis points, which annualizes to $3 \%$ per year.

Consistent with prior literature, Table 3 shows that small, high growth, and high leverage firms tend to have higher stock return volatility. Firms that are performing poorly in terms of ROA and firms with high cash levels also tend to have higher risk (Opler et al. 1999). Firms in which CEOs have higher vega values have lower stock return volatility, possibly owing to the endogeneity of vega (see e.g., Coles, Daniel, and Naveen 2006 and Low 2009). 


\section{Overconfidence and Innovative Activity}

We hypothesize that overconfidence increases innovative investment, as measured by R\&D expenditures, and innovative output, as measured by patents and patent citations.

\subsection{R\&D Expenditures}

To test whether overconfidence causes CEOs to increase spending on innovation as measured by $R \& D$ expenditures, we use $R \& D$ scaled by assets as a dependent variable in the regressions of Table 4. The control variables are similar to those in Coles, Daniel, and Naveen (2006). ${ }^{11}$ The first two rows show that using either the options- or press-based measure, overconfident CEOs spend more on R\&D.

Models (1) and (2) which uses the options-based measure of overconfidence show a positive and significant effect of overconfidence on R\&D. The coefficient in model (1) shows that having an overconfident CEO increases $\mathrm{R} \& \mathrm{D} / \mathrm{Assets}$ by about $0.4 \%$, while model (2) which controls for managerial incentives, show a higher increase of close to $0.8 \%$. Taking the ratio of $0.8 \%$ to the mean level of R\&D/Assets of non-overconfident CEOs of $2.86 \%$ from Table 2 shows that overconfidence increases the amount of R\&D/Assets by about $27 \%$.

Models (3) and (4) use the press-based measure of overconfidence. The qualitative and quantitative conclusions are similar to those using the options-based measure. The coefficient in model (4) shows that having an overconfident CEO, as defined using the press-based measure, increases $\mathrm{R} \& \mathrm{D} / \mathrm{Assets}$ by about $1 \%$. Taking the ratio of this to the mean level of $\mathrm{R} \& \mathrm{D} / \mathrm{Assets}$ of $3.72 \%$ from Panel B of Table 2 shows that overconfidence increases R\&D/Assets by $27 \%$.

\footnotetext{
${ }^{11}$ Coles, Daniel, and Naveen (2006) control for firm size, market-to-book ratio, cash, sales growth, stock return, book leverage, CEO tenure, delta, vega, and cash compensation. We do not control for CEO cash compensation although results are robust to controlling for it. In addition, we also include capital intensity and ROA as control variables.
} 
We find that higher R\&D expenditures are associated with smaller firms and firms with high Tobin's Q, poor operating and stock performance, low leverage, higher capital intensity, and higher cash holdings. Furthermore, as in Coles, Daniel, and Naveen (2006), we find that lower delta values and higher vega values are associated with increased spending on $\mathrm{R} \& \mathrm{D}$. There are several possible interpretations for the coefficients on the control variables. For example, firms with high growth opportunities accumulate cash in order to invest more in the future. Alternatively, it could be that only cash-rich firms are able to invest in R\&D.

\subsection{Patenting Activity}

We now examine the relation between overconfidence and the fruits of innovative activity as proxied by the number of patents the firm applies for in a given year (and eventually receives). The dependent variable is the natural logarithm of one plus patent count. The control variables in the base model are based on Hall and Ziedonis (2001) and Aghion, Van Reenen, and Zingales (2009). Table 5 indicates that overconfident CEOs have higher patent counts.

The base model (1) implies that with the options-based measure, overconfident managers are associated with a patent count that is higher by $9 \%$. The addition of stock returns and institutional holdings leaves the coefficient unchanged in model (2). In model (3), the inclusion of the delta and vega variables causes a modest increase of the coefficient to 0.111 , and the effect becomes more significant $(p<0.05)$.

Reinforcing evidence about the effect of overconfidence on patents is provided by the tests that use the press-based overconfidence measure. The coefficients on overconfidence are higher, ranging from 0.272 to 0.285 , or about $28 \%$ more patents for firms led by overconfident CEOs. The larger economic and statistical significance with the press-based measure is also consistent with the press-based measure being a more stringent measure of overconfidence. 
TotalMention, the number of press articles referring to the $\mathrm{CEO}$, is significantly positive in models (4)-(6). The positive coefficient on TotalMention suggests that firms with more opportunities for innovation are more likely to be covered in the press, so to assess the effect of overconfidence on innovation, it is important to control for press mentions

Together, the evidence from the options- and press-based measures indicates that overconfidence is associated with a substantially greater number of patent grants.

\subsection{Patent Citations}

One measure of the importance of a patent is the number of citations that it receives from subsequent patents. To assess whether overconfidence increases total successful innovative activity, we test whether overconfidence is associated with a greater number of citations to the

firm's patents. Any such effect could come from either greater R\&D investment in innovation or from higher productivity. We later examine the effect of overconfidence on the firm's innovation controlling for R\&D.

Table 6 indicates that firms with overconfident CEOs obtain a greater number of patent citations. The dependent variable is the natural logarithmic transformation of one plus adjusted citation count. Both Qcitation count and TTcitation count are adjusted to take into account truncation bias, as discussed in Section 2.

Using the options-based measure, overconfidence increases Qcitation count by about $17 \%$ and TTcitation count by $11 \%$ in base models (1). The addition of stock returns and institutional holdings decreases the coefficients slightly but the coefficients on the options-based overconfidence measure continue to be significant at conventional levels. In models (3), the addition of the delta and vega variables causes a moderate increase in the size of the coefficients. 
The tests that use the press-based overconfidence measure confirm that overconfidence is associated with greater citation count. The coefficients on overconfidence are significant at the 1$5 \%$ levels, and the effects are even more substantial; overconfident CEOs are associated with Qcitation count being higher by more than $40 \%$ and TTcitation count by more than $20 \%$.

Overall, the evidence indicates that overconfidence is associated with increased patent citations.

\subsection{Industry Innovativeness}

We expect the effect of overconfidence on innovative outcomes to be larger in industries in which good opportunities for innovation are available. We therefore split the sample to perform separate tests of the effect of overconfidence in more- versus less- innovative industries. In addition to providing a test of whether industry is important, a test that is limited to innovative industries is a more powerful way to identify the effects of overconfidence on innovation. For brevity, we focus only on results where all the control variables are included, and show only the coefficients and $t$-statistics associated with the overconfidence measures.

We define an industry as innovative if the average Qcitation count per patent for the industry during the preceding year is greater than the median average Qcitation count across all industries, where industries are classified at the 2-digit SIC level. ${ }^{12}$ The percentage of overconfident CEOs in the innovative industry is somewhat higher than the percentage in the non-innovative industries for both overconfidence measures. Using the options-based measure, the percentage of overconfident CEOs is $63 \%$ in innovative industries and $57 \%$ in non-

\footnotetext{
${ }^{12}$ Innovative industries in our sample include petroleum and natural gas $(\mathrm{SIC}=13)$, commercial machinery $(\mathrm{SIC}=$ $35)$, and communications ( $\mathrm{SIC}=48)$. Non-innovative industries include metal mining and related services (SIC $=$ $10)$, wholesale (durable goods) (SIC $=50)$, and heavy construction $(\mathrm{SIC}=16)$. For the full list of industry classifications, see the online appendix. We alternatively define innovative industry as one where the Qcitation per firm is greater than the median Qcitation per firm across all industries during the year. The main results are robust to the use of this alternative definition.
} 
innovative industries. The corresponding figures using the press-based measure are 9\% and 7\% for innovative and non-innovative industries respectively.

Table 7 shows that overconfidence is associated with higher innovation only within innovative industries. Within innovative industries, the coefficient on overconfidence for both measures is bigger and more statistically significant than in the previous tests that pool across all industries. Using the options-based measure, overconfidence is significantly associated with $16 \%$ higher patent count, 28\% higher Qcitation count, and 17\% higher TTcitation count. In comparison, when pooled across industries, overconfidence is associated with $11 \%$ higher patent count, 18\% higher Qcitation count, and 12\% higher TTcitation count. Tests that use press-based overconfidence measure similarly show that overconfidence is associated with higher patent and citation counts only within innovative industries.

In sharp contrast, within non-innovative industries, the coefficients on the overconfidence measures are close to zero and statistically insignificant. This suggests that overconfidence is associated with greater innovation only within industries where there are substantial opportunities for innovation — either because overconfident managers cause greater innovation, or because of matching wherein firms in industries that have greater opportunities for innovation hire overconfident managers. In Section 5.2.2, we examine whether similar results obtain even in subsamples where selection effects are minimized.

\subsection{Robustness Checks}

In the robustness checks described here, we examine results for the full sample and also for the firms within innovative industries, since focusing on innovative industries provide the most powerful tests of the effects of overconfidence on innovation. The tables associated with most of these robustness checks are in the online appendix. 


\subsubsection{Including Other Control Variables}

As mentioned earlier, our measure of options-based overconfidence differs from that of Malmendier and Tate (2005a, 2008). In their papers, a CEO who failed to exercise her options that are at least $67 \%$ in-the-money and which have five years remaining maturity is classified as overconfident and compared to a CEO in the same situation but who did exercise. This controls for the effect of past performance.

Since we do not have detailed information on CEO's option holdings, we rely on the average moneyness of a CEO's option holdings to classify her as overconfident. As stock options are often granted at the money, the moneyness of options is influenced by stock returns subsequent to the grant date. Thus, the options-based measure could proxy for the relation between past performance and subsequent innovation rather than the effect of a CEO trait. Furthermore, if the press uses the words "confident" or "optimistic" more after firms perform well, the press-based measure might also pick up the effects of performance.

Controlling for stock returns is a stringent test, since managers may become overconfident as a consequence of experiencing strong past performance. So the control is likely to eliminate some of the variation in overconfidence that we wish to measure. Nevertheless, to avoid the possibility of spurious inferences, our main regressions control for buy-and-hold returns over the past fiscal year. However, average moneyness is likely to be influenced by both the CEO's decision not to exercise and the stock performance subsequent to the option grant date. Therefore, to determine the number of years of stock returns we should control for, we run regressions of the natural logarithm of one plus moneyness on several lags of annual stock returns, including the annual stock return leading up to the fiscal year end which moneyness is 
being measured. We also include the natural logarithm of market capitalization as an additional control variable.

We find that the moneyness is significantly associated with contemporaneous stock returns and up to six years of lagged stock returns. Therefore, we use as a control the cumulative stock return over the lesser of the CEO tenure or seven years. The cumulative return stops just before the start of the fiscal year when the dependent variable is measured. Using this alternative return control, we find that both the options-based overconfidence measure and the press-based measure continue to predict greater stock return volatility, $R \& D /$ Assets, patent count, and citation count with similar economic and statistical significance.

In an additional test, following Malmendier, Tate, and Yan (2011) we include five lags of annual stock returns. Since lagged annual returns may include the announcement returns associated with a CEO's appointment for those CEOs appointed within the last five years, we further restrict the sample to CEOs with at least five years of tenure. If the greater innovativeness of overconfident managers has value consequences, this would be reflected at the announcement return of the CEO appointment. Therefore, including the announcement return would tend to subsume the effect we are trying to measure. In this test, the options-based confidence measure is significant in predicting all the dependent variables, with significance levels of $1 \%$ to $5 \%$. The press-based measure significantly predicts all the dependent variables except for TTcitation.

Our controls are similar to those in other studies of the determinants of patent citations. If we also include the additional variables used in our tests of the determinants of R\&D (Tobin's Q, sales growth, ROA, book leverage, and cash), the results are similar to those shown in Table 7. The results which pool across innovative versus non-innovative industries are also generally similar, but not all the tests using the options-based overconfidence measure are statistically 
significant. As discussed earlier, we view tests within innovative industries to be a more powerful way of evaluating the effects of overconfidence.

\section{$\underline{\text { 4.5.2 Robustness of Options-Based and Press-Based Measure }}$}

Our measure of options-based overconfidence measure only requires the CEO to exhibit late exercise once. In Malmendier and Tate (2005a) and Campbell et al. (2011), the CEO is required to exhibit late exercise twice in order to capture a "permanent" rather than "transitory" effect. Therefore, we construct an alternative measure of options-based overconfidence. We identify the first time that the CEO holds a $67 \%$ in-the-money option and classify her as overconfident from this point on provided she subsequently exhibit the same behavior at least once again. Apart from the return volatility results, the economic and statistical significance of effects using this measure are similar.

A possible alternative explanation for the association between the press-based overconfidence measure and innovation proxies is that firms leak stories about forthcoming innovations and say they are "confident" about these projects. To address such reverse causation, we first determine the frequency with which the "confidence" or "optimism" words are applied to projects and other project-related work within our sample of news articles. We randomly select 100 articles from those that referred to the CEO as confident and read them manually to see whether the "confident" or "optimistic" words are used in the context of the CEO's view of the success of a new product or project. We found only 4 articles that seemed potentially to fit the reverse causality scenario, so it is unlikely that reverse causation explains the findings. To further address possible reverse causation, we use a computer algorithm to select articles with words relating to "project" that are within 20 words of confidence-related words: "confident," 
“optimistic," and variants thereof. We delete such articles when forming a cleansed press-based measure; the test results are essentially unchanged. ${ }^{13}$

As shown in Table 2 Panel B, the average number of articles mentioning the CEO is much smaller for the sample of non-overconfident CEOs because we classify CEOs with zero press coverage as non-overconfident; $62 \%$ of firm-years have zero press coverage. When we restrict the sample to the subsample of CEOs for which we have at least one news article, we find that the press-based measure continues to be associated with increased stock return volatility and patent count in the full sample. CEOs' overconfidence is only significantly associated with citation count among firms in innovative industries. There is still a positive point estimate for the effect of overconfidence on $R \& D$, but the coefficient is not statistically significant.

\subsubsection{Self-Citations and Firms with Zero Patents}

Malmendier and Tate (2008) find that overconfident CEOs are more likely to diversify into other industries. To the extent that diversified firms can self-cite across the different lines of business, the citation counts may be different from that of a non-diversified firm of comparable size. We control for whether the firm is a multi-segment firm or single-segment firm and the results remain similar. In another test, we exclude the citations made by patents belonging to the same company when calculating the citation counts and the results remain similar.

There are many firm-years with zero patents or zero citations. To see if the results are driven by the jump from zero patents (zero citations) to at least one patent (citation), we rerun the tests deleting firm-years with zero patents (citations). The press-based measure loses significance

\footnotetext{
${ }^{13}$ The project-related words are 1) innovation, 2) new model, 3) new patent, 4) new product, 5) project, 6) R\&D, and 7) technology; we include variants of these words. Out of the 1106 articles referring to the CEO as confident, only $47(4 \%)$ have a confidence-related word and project-related words within 20 words of each other. When we delete these articles and recalculate the press-based overconfidence measure, we find that only 18 observations out of the original 630 firm-years with overconfident CEOs change their classification from overconfident to nonoverconfident.
} 
for the regressions involving Qcitation and TTcitation for the full sample; the rest of results are quantitatively and qualitatively similar.

\subsubsection{Other Robustness Checks}

Overconfidence could have a longer lagged effect on innovation, so we examine the effect of adding a two year lag on the overconfidence variable and the controls. Both the pressbased and options-based measures continue to predict increased R\&D, patent count and citation count. Although the press-based measure is associated with increased stock return volatility, the options-based measure is no longer so.

Since innovation is important in high-tech industries, and the technology boom of 19982000 was an exceptional period for these industries, we examine the effects of excluding this period from our sample. The results are generally similar, although the statistical significance is slightly lower for the patent and citation count results when measuring overconfidence using the options-based measure.

Finally, we also consider a Negative Binomial model for the prediction of patent count and citation count instead of an OLS regression specification. The results are robust to this alternative estimation method.

\section{Extensions and Alternative Hypotheses}

\subsection{Extensions}

\subsubsection{Average Citations Per Patent}

We have seen that CEO overconfidence is associated with increased patent count and total citation count. The increase in total citations could derive from either more patents or more citations per patent. Our main focus is on the effect of overconfidence on overall innovative productivity as measured by patent count or total citation count. However, it is also interesting to 
see whether overconfident CEOs achieve greater innovation by means of more patents or by patents with higher impact.

In Table 8 we find that overconfident CEOs are associated with increased citation per patent, especially among the firms within innovative industries. The effect is stronger when using Qcitation count. Within innovative industries, an overconfident CEO is associated with Qcitation per patent that is higher by $13 \%$ when overconfidence is measured using the optionsbased measure, and by $19 \%$ when measured using the press-based measure. For TTcitation, the corresponding effects are $3 \%$ and $5 \%$ respectively. Together with findings described earlier, these results indicate that $\mathrm{CEO}$ overconfidence is associated with both a greater number of patents and with higher impact per patent.

\subsubsection{Degrees of Overconfidence}

We next examine whether the relation between innovation and degrees of overconfidence is nonlinear, by forming four groups of CEOs based upon their option-holding behavior. Category 1, non-overconfident CEOs, consists of managers who never hold options that are at least $67 \%$ in-the-money. Category 2, low-overconfidence CEOs, consists of managers who up to the given point in time have held options that are at least $67 \%$ in-the-money but less than $130 \%$ in-the-money. Category 3, moderately overconfident CEOs, consists of managers who up to the given point in time have held options that are at least $130 \%$ in-the-money but less than $250 \%$ inthe-money. Category 4, highly overconfident CEOs, consists of managers who up to the given point in time have held options that are at least $250 \%$ in-the-money.

These cutoffs are chosen such that there are roughly $20 \%$ of CEO-firm-years in each of the overconfident categories: $20 \%$ of the CEO-firm-years are classified as low overconfident, $18 \%$ are classified as moderately overconfident, and $23 \%$ are classified as highly overconfident. 
A CEO can move from a lower level of overconfidence to higher level of overconfidence but cannot move in the opposite direction.

In the regressions, we replace the indicator variable for overconfident with three dummy variables to indicate the 3 levels of overconfidence. The base category is non-overconfident CEOs. The results are presented in Table 9. For brevity, we only show the coefficients on the three overconfidence indicator variables. Each line is from one regression of the dependent variable on the 3 indicator variables and control variables. The control variables for the stock return volatility and $R \& D / A s s e t$ regressions are the same as those in Table 3 model (2). The control variables for the patent count and citation count regressions are the same as those in Table 5 model (3).

The coefficients on the 3 indicator variables increase monotonically for the stock return volatility regression. The low overconfident CEOs are not associated with higher volatility relative to the non-overconfident CEOs. The moderately overconfident CEOs are associated with $12 \%$ higher volatility than the CEOs in the base category, while the highly overconfident CEOs are associated with $28 \%$ greater volatility relative to the base category.

The relation is different for the $\mathrm{R} \& \mathrm{D} /$ Asset regressions. Moderate overconfidence is associated with the greatest increment in R\&D over the base category; highly overconfident CEOs spend similar amounts on R\&D as the non-overconfident CEO. This non-monotonicity is somewhat surprising. A possible explanation is that overconfidence is associated with shifts along two margins of substitution. When overconfidence induces managers to take ambitious, speculative, high-expected-return projects, they will tend to substitute (1) from routine capital expenditures to $R \& D$, and (2) from relative safe $R \& D$ ("D") to more ambitious $R \& D$ ("R"). The first margin tends to increase $R \& D$, but the second margin may either increase or decrease it. If 
margin (2) becomes especially important at high levels of overconfidence, R\&D spending could potentially decline. For example, a highly overconfident manager might cut back on routine incremental development spending on existing products in the expectation that a new initiative will result in "the next big thing," rendering existing products obsolete.

Even though the high overconfidence category is not associated with increased R\&D, it is associated with greater patent count and citation count. The results indicate a U-shaped effect wherein the low overconfident and the highly overconfident CEO categories are associated with greater patent count and patent citation, especially among innovative industries. Moderate overconfidence is not associated with greater patenting activity. ${ }^{14}$

\subsection{Alternative Hypotheses}

We consider here other explanations for our findings associated with alternative interpretations of the overconfidence proxies (private information, differences in risk tolerance, and CEO underestimation of risk), and endogenous matching between CEO and firm characteristics.

\subsubsection{Alternative Interpretations of the Overconfidence Proxies}

\section{Private Information}

The options-based measure of overconfidence may be correlated with private information on the part of the manager, since a manager with favorable information may be inclined to hold

\footnotetext{
${ }^{14}$ In further robustness tests, we vary the moneyness cutoff in intervals of $10 \%$ from $70 \%$ to $250 \%$ to assess the sensitivity of the results to the chosen $67 \%$ cutoff that defines the options-based overconfidence measure. We find that the stock return volatility results are robust to varying the cutoff. For R\&D/Asset, the regression coefficient on the overconfidence measure decreases as we increase the moneyness cutoff when defining overconfident CEOs. This is in part another manifestation of the finding that the highly overconfident CEO category is not associated with increased spending, and partly a result of the fact that for high cutoffs in a test between just two CEO confidence categories, the lower 'non-overconfident' group is likely to contain many overconfident managers. As for patent counts and citation counts, up to a point the regression coefficients on the overconfidence measure decrease as the moneyness cutoff increases, but then the coefficients increase again, i.e., the coefficients are higher when the moneyness cutoff is at the extremes.
} 
the option rather than exercise and sell the stock. Such favorable information could then explain strong subsequent performance in patents and citations.

However, private information should be fairly short-lived, whereas our overconfidence measures are persistent. Malmendier and Tate (2005a) find that overconfident CEOs are late exercisers persistently over time, and do not earn abnormal returns through their decision not to exercise. Furthermore, Carpenter and Remmers (2001) report that there is almost no evidence that managers exercise options based upon inside information. So it is unlikely that the effects of overconfidence identified here derive from inside information. Also, the press-based measure of overconfidence is based upon public information and hence is not a proxy for inside information.

Furthermore, the private information argument suggests that non-exercising CEOs will make better investments. The evidence of Malmendier and Tate (2008) is exactly the opposite; acquisitions made by overconfident CEOs perform less well.

A special case of the private information argument is that managers refrain from exercising their options in order to signal favorable information. Malmendier and Tate (2005a) argue that option non-exercise is an implausible vehicle for signaling firm value, and that the financial press and financial advisory firms do not focus on exercise as a value indicator. However, we emphasize that signaling motives do not present any special problem for the options-based measure above and beyond the issue of private information discussed above.

Another variant of the private information argument is that the CEO knows that she is talented, even if the market does not know. In this case, the CEO may delay option exercise or use words such as "confident" more often when addressing the press. Therefore, our overconfidence measures may just proxy for CEO ability. However, the evidence that overconfident CEOs tend to make bad acquisitions opposes this view. 


\section{Risk-Tolerance}

A possible alternative explanation for our findings is that managers who refrain from option exercise are more risk tolerant rather than more overconfident. High risk tolerance could then result in greater risk-taking and greater innovation. Furthermore, some of the words used to identify overconfidence using the press-based measure may also be indicators of risk tolerance.

Even if this interpretation were true, it would not overturn one of the key insights of this paper, that there are managerial traits systematically associated with greater innovation. Furthermore, as pointed out by Malmendier and Tate (2005a), their evidence that their optionsbased overconfidence measure is associated with lower investment-cash flow sensitivity is inconsistent with it being a proxy for higher risk-tolerance. Less risk-averse managers should be more willing to leverage up the firm if necessary to finance investment projects. Malmendier and Tate (2005b) find similar results with the press-based measure of overconfidence.

\section{Underestimation of Risk}

A possible concern about the options-based measure is that instead of just overestimating the expected profitability of undertaking new projects, an overconfident CEO may overestimate the precision of his beliefs about the future, and therefore underestimate stock volatility. In one way this reinforces the argument for the option measure. Underestimation of risk implies overvaluing the stock, which should discourage a CEO from exercising and selling.

However, no-arbitrage option pricing theory implies that volatility increases the value of the option feature. As discussed by Malmendier, Tate, and Yan (2011), underestimation of risk could encourage overconfident managers to exercise options early instead of late. If so, the options-based measure could alternatively proxy for underconfidence. 
This would be quite surprising, given evidence from several papers (including the current one) that the options-based measure is associated with corporate behaviors predicted by overconfidence, and yields results very similar to the press-based option measure (Malmendier and Tate 2005a, 2005b, 2008). Furthermore, it is invalid to value a CEO option using noarbitrage option pricing theory, since CEOs cannot perform the required costless riskfree dynamic hedging strategy (Campbell et al. 2011). Under expected utility theory, there is an opposing effect: the lower perceived volatility of an option reduces the perceived cost of holding risky options, which can lead to late exercise.

Overall, theoretical analysis indicates that the effect of higher variance on option value is nonmonotonic (Carpenter, Stanton, and Wallace 2010); empirically high realized variance is associated with earlier exercise of executive options (Bettis, Bizjak, and Lemmon 2005, Carpenter, Stanton, and Wallace 2009). This suggests that underestimating variance should favor later exercise - consistent with the options-based measure being a proxy for overconfidence, both in the sense of overestimating the mean and underestimating the variance.

\subsubsection{Matching between CEO Overconfidence and Firm Characteristics}

There are two causally distinct interpretations of the results so far. One is that overconfidence causes managers to overestimate their prospects for success in risky endeavors such as innovation. The other is that firms with strong opportunities for innovative projects appoint overconfident CEOs. Several authors propose that height is an overconfidence proxy; Graham, Harvey, and Puri (2010) find that growth firms tend to have more confident CEOs using this proxy, consistent with matching between manager and firm. Of course, matching is entirely compatible with overconfidence having a causal effect on innovation. Indeed, this is the most obvious explanation for why firms would want to engage in matching. 
To gain insight about whether our findings are driven by a causal effect of managers on innovation or solely by matching, we now restrict our sample to a subset of firm-years for which matching is likely to be less important. CEO overconfidence in our tests is a persistent trait. In contrast, a firm's growth opportunities vary over time as its strategic resources and competitive environment shift. This suggests that matching effects between CEO overconfidence and timevarying firm characteristics are likely to be strongest when the CEO is first appointed. We therefore reexamine the effects of overconfidence after eliminating from the sample all firmyears in which the manager is new, and vary the tenure cutoff from four years to six years.

Table 10 summarizes the coefficients on the confidence measures. Each cell in Table 10 is from a regression of the dependent variable on either the options-based or press-based measure and control variables. The model specifications are the same as those in Table 3 model (2) for the stock return volatility and R\&D/Asset regressions and Table 5 model (3) for the patent count and citation count regressions. For ease of comparison, columns 1 and 2 repeat the results from the previous tables in which all firm-years are included. The remaining columns show results for different tenure cutoffs for the full sample and the subsample of innovative industries.

The press-based overconfidence measure continues to be positively related to stock return volatility, with similar magnitude of effect, regardless of tenure cutoff. The results for the options-based measure are economically similar across tenure cutoff, but with weaker statistical significance for some subsamples. For all innovation measures, the coefficients on the overconfidence measures remain statistically significant and are as high or higher for managers with longer tenures. These findings suggest that the relation between CEO overconfidence and innovation does not come mainly from the endogenous selection of overconfident CEOs by 
innovative firms. This conclusion is intuitive; it would be surprising if innovative firms continued to seek overconfident CEOs if overconfidence were not useful for business needs.

Patents and citation counts may take a long time to arrive, so a CEO associated with increased innovation may just be reaping the benefits of policies put in place before his tenure starts. By verifying the robustness of the results to excluding short-tenure CEOs, these tests provide assurance that the main findings are driven by the $\mathrm{CEO}$ whose overconfidence we are measuring.

\section{Overconfidence, Innovative Efficiency, and Firm Performance}

The evidence provided so far is consistent either with overconfident CEOs increasing firm value through effective innovation, or with their increasing innovation by means of valuereducing overspending on $\mathrm{R} \& \mathrm{D}$. To explore which is the case, we first examine whether overconfident CEOs increase the effectiveness of their R\&D investment in generating patents and citations. Next we examine the relation of CEO overconfidence to firm value.

\subsection{Innovative Efficiency}

We have found that managerial overconfidence increases patent applications and patent citations. But since we have also found that managerial overconfidence increases R\&D investment, the question remains open of whether managerial overconfidence increases or decreases the effectiveness of the manager in generating innovation for any given level of R\&D expenditure. To test whether managerial overconfidence improves the effectiveness of the firm in generating innovation, we regress patent count and citation count on the overconfidence measures and add the natural logarithm of one plus lagged R\&D/Asset to the set of controls. ${ }^{15}$

\footnotetext{
${ }^{15}$ We include lagged R\&D spending. In additional robustness checks, following Hall and Ziedonis (2001) we control for contemporaneous R\&D spending instead. Results are similar to those in Table 11. We also tried scaling
} 
In Table 11 for brevity, we show results for the innovative industries and non-innovative industries. ${ }^{16}$ The coefficients on the overconfidence variables among the firms in innovative industries are all positive and significant, although smaller than the corresponding coefficients in Table 7, suggesting that some of the effects of overconfidence on innovative output found earlier derive from increased $R \& D$ spending by overconfident CEOs. Nevertheless, for a given level of R\&D, overconfidence increases the effectiveness of innovation. Therefore, both increased R\&D spending and increased effectiveness of that spending contribute to the overall innovative productivity of overconfident CEOs. For firms in the non-innovative industries, none of the coefficients on the overconfidence measures are significant.

Within innovative industries, the options-based measure of overconfidence is associated with about $11 \%$ higher patent count, $20 \%$ higher Qcitation count, and $12 \%$ higher TTcitation count. The economic effects are larger when using the press-based measure. The press-based overconfidence measure is associated with 27\% higher patent count, 35\% higher Qcitation count, and $24 \%$ higher TTcitation count. Overall, the evidence shows that within innovative industries, overconfident CEOs are associated with greater patent citations even after controlling for the amount of innovative investment.

This is surprising, as we typically expect biased perceptions to lead to error and inefficiency. A possible explanation is that the projects undertaken by overconfident managers generate patents and citations but not market value. We do not rule out this possibility; however, evidence from Hall, Jaffe, and Trajtenberg (2005) does indicate that patent citations are on

R\&D with sales and net property, plant, and equipment with sales; similar results continue to hold within innovative industries. In another test, we control for size using number of employees and scale R\&D and net property, plant, and equipment with number of employees; similar results continue to hold within innovative industries.

${ }^{16}$ For the full sample, although the coefficients are positive, the options-based measure is not significant for any of the three dependent variables. The press-based measure is generally positive and significant, albeit at the $10 \%$ level when predicting patent count and Qcitation count, and is insignificant when predicting TTcitation count. 
average positively related to firm value. In the next section, we relate overconfidence to the ability to exploit growth opportunities and translate external growth opportunities into firm value.

Another possible explanation is that rational risk-averse managers may be too reluctant to take risky but high-expected-return projects. If so, managerial overconfidence can help stockholders by encouraging desirable risk-taking. Indeed, this may help explain the puzzle of why overconfident managers are permitted to rise to the CEO position in many firms. ${ }^{17}$

Since in Table 9 we saw that highly overconfident CEOs do not spend more on R\&D, it is interesting to see how innovation varies with degree of overconfidence after controlling for R\&D. The results are similar to those in Table 9. Within the innovative industries, we still find a U-shaped pattern wherein the low overconfident CEOs and the highly overconfident CEOs are associated with greater innovation even after controlling for R\&D.

\subsection{Firm Value}

Our proposed solution to the overconfident manager puzzle, that overconfident managers are more willing to undertake risky but valuable innovation, suggests that overconfident CEOs do not necessarily harm firm value, despite evidence in previous literature that overconfident CEO undertake bad merger and acquisitions (Malmendier and Tate 2008). However, endogeneity issues would hamper the interpretation of a regression of firm value on CEO overconfidence. We therefore examine a more specific issue, whether overconfidence allows firms to translate growth opportunities to realized firm value.

A challenge for this approach is to find an exogenous proxy for firm growth opportunities. Following Bekaert et al. (2007), we use industry price to earnings (PE) ratio as an exogenous

\footnotetext{
${ }^{17}$ We also examine whether overconfidence is associated with increased citation count per patent after controlling for R\&D expenditures. The effects are weak. Although all the coefficients on both the measures of overconfidence are positive, only the options-based measure is significantly associated with increased Qcitation count $(p<0.10)$ per patent within the innovative industries. Neither measure significantly predicts increased TTcitation count.
} 
instrument for firm growth. We calculate the monthly industry PE ratio as the logarithmic transformation of the ratio of industry's total market capitalization to the industry's total earnings. $\mathrm{PE}$ is affected by risk as well as the growth opportunities, so our tests are weakened by noise to the extent that the PE ratio is influenced by discount rate changes. As in Bekaert et al., we therefore subtract the 60-month moving average of the PE ratio, motivated by the idea that discount rates are more persistent than growth opportunities. Finally, we average the difference over the fiscal year to form our measure of exogenous growth opportunities.

To test whether overconfident CEOs are more able to transform growth opportunities into firm value, we interact our measure of growth opportunities with our measures of overconfidence. The measure of firm value is Tobin's Q. All the independent variables are lagged by one year. If the stock market is efficient, any effects of overconfidence should be impounded in the one-year future Q.

Table 12, Panel A shows the results. Column 1 shows that the industry growth measure positively and significantly predicts Tobin's $Q$, which suggests that it does capture growth opportunities. The interaction between growth opportunity and the options-based measure is positive and significant for both the full sample and within innovative industries. There is no such pattern for the non-innovative industries. To ensure that this result is not driven by the options-based measure proxying for past stock returns, we also include an interaction between past stock returns and the growth opportunity measure. To verify robustness, we also use the cumulative returns over the lesser of the CEO tenure or the past seven years. The results remain similar. For the press-based measure, the coefficient on the interaction term between overconfidence and growth opportunity is positive but not significant. The coefficients on the 
stand-alone overconfidence variables are positive and significant in some of the regressions, but owing to endogeneity concerns the economic meaning of this is unclear.

In Panel B, we divide the CEOs into groups based on their level of overconfidence. Interestingly, we find that the highly overconfident CEOs are the ones most able to transform growth opportunities into firm value. Again, the effects are only present among the innovative industries.

As discussed earlier, firms with overconfident CEOs tend to have higher return volatility, so the options-based measure may be picking up a volatility effect. However, when we include stock return volatility and the interaction of the stock return volatility with the growth opportunity measure as additional controls, the results remain similar.

\section{Concluding Remarks}

Using proxies for CEO overconfidence based upon options exercise and press coverage, we find that over the 1993-2003 period, CEO overconfidence is associated with riskier projects, greater investment in innovation, and greater total quantity of innovation as measured by patent applications and patent citations even after controlling for the amount of R\&D expenditure. In other words, the R\&D investments of overconfident CEOs are more productive in generating innovation. Greater innovative output of overconfident managers is achieved only in innovative industries. Using the industry price-to-earnings ratio as an exogenous instrument, we also find evidence that overconfident CEOs are more effective at exploiting growth opportunities and translating them into firm value. Again, this finding applies only within innovative industries. We find that overconfidence remains a strong and significant predictor of innovation even when we remove managers with short tenures at their firms, which suggests that the endogenous hiring of overconfident managers by innovative firms is not the main driver of our findings. 
The results of this study have a bearing on the usual presumption that overconfidence is undesirable. Business commentators often point to examples of headstrong, overconfident CEOs who made disastrous decisions. However, the chance of a big defeat may be a corollary to the chance of great victory, so the lesson to draw from examples is unclear. A more serious charge is provided by the evidence of Malmendier and Tate (2008) that the market reacts more negatively to acquisitions made by overconfident CEOs. This dark side to CEO overconfidence might seem to suggest that the CEO selection process should be designed to filter out oversized egos, or that compensation and governance should be designed to severely constrain such CEOs.

On the other hand, some authors have suggested positive roles for overconfidence, such as improving decision implementation (Russo and Schoemaker 1992), encouraging agents to take sufficient risk on behalf of principals (Goel and Thakor 2008, Gervais, Odean, and Heaton 2011), or countering information externality problems by stimulating entrepreneurship and experimentation (Bernardo and Welch 2001). Vinod Khosla, co-founder of Sun Microsystems Inc. and venture capitalist, describes "unbridled confidence and arrogance," as key characteristics for successful business visionaries. ${ }^{18}$ Our tests identify empirically a positive side to CEO overconfidence. Why would overconfidence adversely affect acquisition decisions, yet favorably affect innovation decisions? This may be a natural consequence of the bright sides and the dark sides of CEO overconfidence. We have argued, consistent with Goel and Thakor (2008) and Gervais, Heaton, and Odean (2011), that if managers are risk averse, the willingness to take audacious risks can be valuable to the firm. However, overconfidence may have more adverse effects for external acquisition than for internally-driven innovation. Self-aggrandizing CEOs

\footnotetext{
18 "Who Will Be the 'Next Steve Jobs'?," Wall Street Journal, 10/8/11, http://online.wsj.com/article/SB10001424052970203476804576617432977807982.html.
} 
may engage in excessive empire-building through acquisition because they overestimate their ability to exert effective control over a wider domain.

The effects of overconfidence on innovation are mainly found in innovative industries, which suggest that the benefits of overconfidence for internal innovative investments weigh especially heavily in industries in which firms have strong internal innovative opportunities. In contrast, in industries that lack good opportunities for internal innovation, overconfident CEOs may be more likely to resort to bad acquisitions.

Our findings therefore suggest a possible solution to the puzzle of why so many firms hire overconfident CEOs and CFOs (Malmendier and Tate 2005a, 2008, Ben-David, Graham and Harvey 2010), and why such CEOs seem to be placed at the helm of growth firms (Graham, Harvey and Puri 2010)—exactly the kind of firm in which overconfidence will have the greatest effect. The hiring of such managers, and their matching with growth firms, may be efficient if overconfident CEOs are better innovators. 


\section{References}

Aghion, Philippe, John Van Reenen, and Luigi Zingales, 2009, "Innovation and Institutional Ownership,” NBER Working Paper 14769.

Baker, Malcolm, Xin Pan, and Jeffrey Wurgler, 2009, “A Reference Point Theory of Mergers and Acquisitions," Working Paper, Harvard Business School and New York University.

Bekaert, Geert, Campbell R. Harvey, Christian Lundblad, and Stephan Siegal, 2007, "Global Growth Opportunities and Market Integration,” Journal of Finance 62, 1081-1137.

Ben-David, Itzhak, John R. Graham, and Campbell R.Harvey, 2010, "Managerial Miscalibration," Working Paper, Fisher College of Business, Ohio State University.

Benabou, Roland and Jean Tirole, 2002, "Self-Confidence and Personal Motivation," Quarterly Journal of Economics 117, 871-915.

Bernardo, Antonio and Ivo Welch, 2001, "On the Evolution of Overconfidence and Entrepreneurs," Journal of Economics and Management Strategy 10, 301-330.

Bertrand, Marianne and Antoinette Schoar, 2003, "Managing with Style: The Effect of Managers on Firm Policies," Quarterly Journal of Economics 118, 1169-1208.

Bettis, J. Carr, John Bizjak, and Michael Lemmon, 2005, "Exercise Behavior, Valuation, and the Incentive Effects of Employee Stock Options," Journal of Financial Economics 76, 445-470.

Billett, Matthew and Yiming Qian, 2008, “Are Overconfident CEOs Born or Made? Evidence of Self-Attribution Bias from Frequent Acquirers,” Management Science 54, 1037-1051.

Brenner, Lyle, Derek J. Koehler, Varda Liberman, and Amos Tversky, 1996, "Overconfidence in Probability and Frequency Judgments: A Critical Examination," Organizational Behavior and Human Decision Processes 65, 212-219.

Campbell, T. Colin, Michael Gallmeyer, Shane Johnson, Jessica Rutherford, and Brooke Stanley, 2011, “CEO Optimism and Forced Turnover," Journal of Financial Economics 101, 695-712.

Carpenter, Jennifer and Barbara Remmers, 2001, "Executive Stock Option Exercises and Inside Information," Journal of Business, 74, 513-534.

Carpenter, Jennifer, Richard Stanton, and Nancy Wallace, 2009, "Estimation of Employee Stock Option Exercise Rates and Firm Cost," Working Paper, University of California, Berkeley.

Carpenter, Jennifer, Richard Stanton, and Nancy Wallace, 2010, "Optimal Exercise of Executive Stock Options and Implications for Firm Cost," Journal of Financial Economics, 98, 315-337. 
Coles, Jeffrey, Naveen Daniel, and Lalitha Naveen, 2006, "Managerial Incentives and Risktaking," Journal of Financial Economics, 79, 431-468.

Core, John and Wayne Guay, 2002, "Estimating the Value of Employee Stock Option Portfolios and their Sensitivities to Price and Volatility," Journal of Accounting Research 40, 613-630.

DeBondt, Werner and Richard Thaler, 1995, "Financial Decision Making in Markets and Firms: A Behavioral Perspective," in R. Jarrow, V Maksimovic, and W Ziemba, eds, Finance, Handbooks in Operations Research and Management Science, Amsterdam: Elsevier-North Holland.

Einhorn, Hillel, 1980, “Overconfidence in Judgment," New Directions for Methodology of Social and Behavioral Science 4, 1-16.

Galasso, Alberto and Timothy Simcoe, 2010, “CEO Overconfidence and Innovation,” Working Paper, Boston University.

Gervais, Simon, J. B. Heaton, and Terrance Odean, 2011, “Overconfidence, Compensation Contracts, and Capital Budgeting," Journal of Finance 66, 1735-1777.

Gigerenzer Gerd, Hoffrage Ulrich, and Heinz Kleinbölting 1991, "Probabilistic Mental Models: A Brunswikian Theory of Confidence," Psychological Review 98, 506-528.

Goel, Anand and Anjan Thakor, 2008, “Overconfidence, CEO Selection, and Corporate Governance," Journal of Finance 63, 2737-2784.

Graham, John, Campbell Harvey, and Manju Puri, 2010, "Managerial Attitudes and Corporate Actions," Working Paper, Duke University.

Griffin, Dale and Amos Tversky, 1992, "The Weighing of Evidence and the Determinants of Confidence," Cognitive Psychology 24, 411-435.

Griliches, Zvi, Ariel Pakes, and Bronwyn Hall, 1987, "The Value of Patents as Indicators of Inventive Activity," in P. Dasgupta and P. Stoneman, eds., Economic Policy and Technological Performance, Cambridge England: Cambridge University Press.

Hall, Brian and Kevin Murphy, 2002, "Stock Options for Undiversified Executives," Journal of Accounting and Economics 33, 3-42.

Hall, Bronwyn, Adam Jaffe, and Manuel Trajtenberg, 2001, "The NBER Patent Citations Data File: Lessons, Insights and Methodological Tools,” NBER Working Paper 8498.

Hall, Bronwyn, Adam Jaffe, and Manuel Trajtenberg, 2005, "Market Value and Patent Citations," RAND Journal of Economics 36, 16-38.

Hall, Bronwyn and Rosemarie Ziedonis, 2001, “The Patent Paradox Revisited: An Empirical 
Study of Patenting in the U.S. Semiconductor Industry, 1979-1995," RAND Journal of Economics 32, 101-128.

Hribar, Paul and Holly Yang, 2011, "CEO Overconfidence and Management Forecasting," Working Paper, University of Iowa.

Kaplan, Steven and Bernadette Minton, 2008, "How Has CEO Turnover Changed?" Working Paper, Ohio State University.

Koontz, Harold and Heinz Weihrich, 2007, Essentials of Management: An International Perspective, New Delhi: Tata McGraw-Hill.

Liu, Yue and Richard Taffler, 2008. "CEO Overconfidence in M\&A Decision Making and its Impact on Firm Performance,” Working Paper, University of Edinburgh.

Low, Angie, 2009, "Managerial Risk-Taking Behavior and Equity-Based Compensation," Journal of Financial Economics 92, 470-490.

Malmendier, Ulrike and Geoffrey Tate, 2005a. "CEO Overconfidence and Corporate Investment," Journal of Finance 60, 2661-2700.

Malmendier, Ulrike and Geoffrey Tate, 2005b. "Does Overconfidence Affect Corporate Investment? CEO Overconfidence Measures Revisited," European Financial Management 11, 649-659.

Malmendier, Ulrike and Geoffrey Tate, 2008, "Who Makes Acquisitions? CEO Overconfidence and the Market's Reaction," Journal of Financial Economics 89, 20-43.

Malmendier, Ulrike, Geoffrey Tate, and Jon Yan, 2011, "Overconfidence and Early-Life Experiences: The Effect of Managerial Traits on Corporate Financial Policies," Journal of Finance 66, 1687-1733.

Opler, Tim, Lee Pinkowitz, René Stulz, and Rohan Williamson, 1999, "The Determinants and Implications of Corporate Cash Holdings," Journal of Financial Economics 52, 3-46.

Oskamp, Stuart, 1965, "Overconfidence in Case Study Judgments," Journal of Consulting Psychology 29, 261-265.

Puri, Manju and David Robinson, 2007, "Optimism and Economic Choice," Journal of Financial Economics 86, 71-99.

Rabin, Matthew, 1998, "Psychology and Economics." Journal of Economic Literature 36, 11-46.

Russo, J. Edward and Paul Schoemaker, 1992, “Managing Overconfidence," Sloan Management Review 33, 7-17. 
Schrand, Catherine and Sarah Zechman, 2010, "Executive Overconfidence and the Slippery Slope to Fraud," Working Paper, University of Chicago.

Trajtenberg, Manuel, 1990, “A Penny for Your Quotes: Patent Citations and the Value of Innovations," RAND Journal of Economics 21, 172-187.

Van den Steen, Eric, 2004, "Rational Overoptimism (and Other Biases)," American Economic Review, 94, 1141-1151.

Wagenaar, Willem and Gideon Keren, 1986, "Does the Expert Know? The Reliability of Predictions and Confidence Ratings of Experts," In E. Hollnagel, G. Mancini, and D. Woods, eds Intelligent Decision Support in Process Environment, Berlin: Springer.

Weinstein, Neil, 1980, “Unrealistic Optimism about Future Life Events," Journal of Personality and Social Psychology 39, 806-820. 


\section{Appendix A}

This appendix defines the variables used in the study. Accounting data is from Compustat, stock return data from CRSP, patent data is from the NBER patent dataset, and compensation data from Execucomp.

\begin{tabular}{|c|c|}
\hline Variables & Description \\
\hline \multicolumn{2}{|l|}{ Dependent variables } \\
\hline Stock return volatility & Standard deviation of daily stock returns over the year \\
\hline $\mathrm{R} \& \mathrm{D} /$ Assets & $\begin{array}{l}\text { Research and development expenditures scaled by book assets. Missing values are } \\
\text { coded with zero }\end{array}$ \\
\hline Patent & No. of patents applied for during the year \\
\hline Citation (raw) count & Total number of citations summed across all patents applied for during the year \\
\hline Qcitation count & $\begin{array}{l}\text { Total number of citations summed across all patents applied for during the year. } \\
\text { Each patent's no. of citations is multiplied by the weighting index from Hall, Jaffe, } \\
\text { and Trajtenberg }(2001,2005)\end{array}$ \\
\hline TTcitation count & $\begin{array}{l}\text { Total number of citations summed across all patents applied for during the year. } \\
\text { Each patent's no. of citations is divided by the average citation count of all patents in } \\
\text { the same technology class and applied in the same year }\end{array}$ \\
\hline \multicolumn{2}{|c|}{ Variables relating to CEO overconfidence, lagged values } \\
\hline Confident CEO (Options) & $\begin{array}{l}\text { Options-based measure of CEO overconfidence. Indicator variable equals to one for } \\
\text { all years after a CEO holds options that are at least } 67 \% \text { in-the-money, and zero } \\
\text { otherwise }\end{array}$ \\
\hline Confident CEO (Press) & $\begin{array}{l}\text { Press-based measure of CEO overconfidence. Indicator variable equals one when the } \\
\text { no. of "confident" articles for a CEO in Factiva is greater than the no. of "cautious" } \\
\text { articles, and zero otherwise }\end{array}$ \\
\hline TotalMention & No. of articles mentioning the CEO \\
\hline \multicolumn{2}{|c|}{ Other independent variables, lagged values } \\
\hline Sales & Firm sales in millions of 2006 dollars \\
\hline PPE/Emp & Net property, plant, and equipment per employee in thousands of 2006 dollars \\
\hline Stock return & Buy-and-hold return over the fiscal year \\
\hline Tobin's Q & Ratio of market value to book value of assets \\
\hline Sales growth & Log transformation of sales divided by prior year sales \\
\hline ROA & Return on assets, ratio of operating income before depreciation to book assets \\
\hline Book leverage & Ratio of sum of long-term debt and short-term debt to book assets \\
\hline Cash & Ratio of cash to book assets \\
\hline CEO tenure & CEO tenure in months \\
\hline CEO delta & $\begin{array}{l}\text { Dollar change in CEO stock and option portfolio for } 1 \% \text { change in stock price, in } \\
\text { thousands of } 2006 \text { dollars }\end{array}$ \\
\hline CEO vega & $\begin{array}{l}\text { Dollar change in CEO option holdings for a } 1 \% \text { change in stock return volatility, in } \\
\text { thousands of } 2006 \text { dollars }\end{array}$ \\
\hline Institutional holdings & Percentage of shares held by financial institutions, averaged over the fiscal year \\
\hline Innovative industry & $\begin{array}{l}\text { An industry is innovative if the Qcitation count per patent for the industry is greater } \\
\text { than the median Qcitation count per patent across all industries for the year }\end{array}$ \\
\hline Industry PE & $\begin{array}{l}\text { Average monthly industry PE over the fiscal year. The monthly industry PE is } \\
\text { calculated as the log transformation of the industry's total market capitalization to } \\
\text { total earnings less a } 60 \text {-month moving average }\end{array}$ \\
\hline \# segments & No. of business segments \\
\hline
\end{tabular}




\section{Table 1. Frequency of overconfident CEOs}

The table gives the yearly breakdown of the number of CEOs, number of overconfident CEOs, and percentage of overconfident CEOs in our sample. Sample of CEOs is from Execucomp from 1993 to 2003. Financial and utility firms are deleted. We require that firms have accounting data from Compustat, stock returns data from CRSP, and patent data from the NBER patent dataset. The options-based measure of CEO overconfidence defines a CEO as being overconfident after he holds options that are at least $67 \%$ in-the-money. The press-based measure of CEO overconfidence defines a CEO as being overconfident when the number of 'confident' articles for a CEO in Factiva exceeds the number of 'cautious' articles. For brevity, overconfident CEOs are labeled as 'confident' in the tables.

\begin{tabular}{|c|c|c|c|c|c|c|}
\hline \multirow[b]{2}{*}{ Year } & \multicolumn{3}{|c|}{ Options-based measure } & \multicolumn{3}{|c|}{ Press-based measure } \\
\hline & $\begin{array}{l}\text { No. of } \\
\text { CEOs }\end{array}$ & $\begin{array}{c}\text { Confident } \\
\text { CEOs (\#) }\end{array}$ & $\begin{array}{r}\text { nfident } \\
\text { CEOs } \\
(\%)\end{array}$ & $\begin{array}{l}\text { No. of } \\
\text { CEOs }\end{array}$ & $\begin{array}{l}\text { Confident } \\
\text { CEOs (\#) }\end{array}$ & $\begin{array}{r}\text { Confident } \\
\text { CEOs } \\
(\%)\end{array}$ \\
\hline 1993 & 473 & 193 & 40.80 & 400 & 6 & 1.50 \\
\hline 1994 & 682 & 347 & 50.88 & 565 & 18 & 3.19 \\
\hline 1995 & 723 & 363 & 50.21 & 584 & 25 & 4.28 \\
\hline 1996 & 777 & 443 & 57.01 & 633 & 30 & 4.74 \\
\hline 1997 & 831 & 523 & 62.94 & 690 & 51 & 7.39 \\
\hline 1998 & 886 & 613 & 69.19 & 763 & 49 & 6.42 \\
\hline 1999 & 911 & 622 & 68.28 & 818 & 72 & 8.80 \\
\hline 2000 & 874 & 597 & 68.31 & 797 & 88 & 11.04 \\
\hline 2001 & 856 & 575 & 67.17 & 783 & 86 & 10.98 \\
\hline 2002 & 935 & 600 & 64.17 & 846 & 96 & 11.35 \\
\hline 2003 & 991 & 584 & 58.93 & 883 & 109 & 12.34 \\
\hline Total & 8939 & 5460 & 61.08 & 7762 & 630 & 8.12 \\
\hline
\end{tabular}




\section{Table 2. Summary statistics}

The table gives the means and medians of the variables used in this study. The sample consists of all non-financial and non-utility firms in Execucomp from 1993 to 2003. To be included in the sample, firms are required to have accounting data from Compustat, patent data from the NBER patent dataset, and stock returns data from CRSP. Panel A divides the firms based on the options-based measure of CEO overconfidence. Panel B divides the firms based on the press-based measure of CEO overconfidence. The options-based measure of CEO overconfidence defines a CEO as being overconfident after he holds options that are at least $67 \%$ in-the-money. The press-based measure of CEO overconfidence defines a CEO as being overconfident when the number of 'confident' articles for a CEO in Factiva exceeds the number of 'cautious' articles. For brevity, overconfident CEOs are labeled as 'confident' in the tables. Definitions of the variables are provided in Appendix A. T-tests (Wilcoxon-Mann-Whitney tests) are conducted to test for differences between the means (medians) for the firms with overconfident CEOs and firms with non-overconfident CEOs. *, **, and *** measure significance at the $10 \%, 5 \%$, and $1 \%$ level, respectively.

\section{Panel A. Options-based measure of confidence}

\begin{tabular}{|c|c|c|c|c|c|c|}
\hline \multirow[b]{2}{*}{ Variable } & \multicolumn{3}{|c|}{ Non-confident CEO $(N=3479)$} & \multicolumn{3}{|c|}{ Confident CEO $(N=5460)$} \\
\hline & Mean & Median & Std. dev. & Mean & Median & Std. dev. \\
\hline \multicolumn{7}{|l|}{ Dependent variables } \\
\hline Stock return volatility (\%) & 2.66 & 2.28 & 1.38 & $3.19 * * *$ & $2.86 * * *$ & 1.49 \\
\hline R\&D/Assets (\%) & 2.86 & 0.14 & 6.69 & $4.59 * * *$ & $0.85 * * *$ & 8.71 \\
\hline No. of patents & 23.43 & 0.00 & 108.23 & $31.98 * * *$ & 0.00 & 172.58 \\
\hline Citation (raw) count & 146.97 & 0.00 & 992.21 & $212.33 * * *$ & 0.00 & 1392.66 \\
\hline Qcitation count & 306.04 & 0.00 & 1792.29 & $550.16 * * *$ & 0.00 & 3465.50 \\
\hline TTcitation count & 27.63 & 0.00 & 128.00 & $40.32 * * *$ & 0.00 & 221.40 \\
\hline Citation count per patent & 2.75 & 0.00 & 6.29 & 2.88 & 0.00 & 6.96 \\
\hline Qcitation count per patent & 5.96 & 0.00 & 12.55 & $7.02 * * *$ & 0.00 & 13.99 \\
\hline TTcitation count per patent & 0.51 & 0.00 & 0.96 & $0.56 * *$ & 0.00 & 0.97 \\
\hline \multicolumn{7}{|l|}{ Control variables } \\
\hline$\overline{\text { Sales }}$ & 4893.05 & 1459.58 & 9106.08 & $3737.15 * * *$ & $974.85 * * *$ & 7961.39 \\
\hline PPE/Emp & 191.69 & 55.77 & 441.29 & $130.47 * * *$ & $44.27 * * *$ & 374.49 \\
\hline Stock return & 0.06 & 0.04 & 0.43 & $0.27 * * *$ & $0.15 * * *$ & 0.72 \\
\hline Tobin's Q & 1.63 & 1.37 & 0.95 & $2.55 * * *$ & $1.86 * * *$ & 2.21 \\
\hline Sales growth & 0.05 & 0.05 & 0.20 & $0.16 * * *$ & $0.13 * * *$ & 0.27 \\
\hline $\mathrm{ROA}$ & 0.13 & 0.14 & 0.09 & $0.15 * * *$ & $0.16 * * *$ & 0.11 \\
\hline Book leverage & 0.26 & 0.26 & 0.16 & $0.21 * * *$ & $0.20 * * *$ & 0.17 \\
\hline Cash & 0.09 & 0.04 & 0.14 & $0.16 * * *$ & $0.07 * * *$ & 0.19 \\
\hline Institutional holdings & 56.56 & 58.74 & 17.76 & $60.19 * * *$ & $62.10 * * *$ & 18.46 \\
\hline Industry PE & 0.15 & 0.12 & 0.52 & $0.10 * * *$ & $0.11 * *$ & 0.50 \\
\hline \# segments & 2.24 & 2.00 & 1.45 & $1.90 * * *$ & $1.00 * * *$ & 1.30 \\
\hline CEO tenure & 70.53 & 41.00 & 84.22 & $106.48 * * *$ & $84.00 * * *$ & 85.52 \\
\hline CEO delta & 341.00 & 123.16 & 962.93 & $933.40 * * *$ & $305.27 * * *$ & 2403.40 \\
\hline CEO vega & 100.84 & 45.30 & 163.22 & $127.53 * * *$ & $47.26 * *$ & 251.10 \\
\hline
\end{tabular}


Panel B. Press-based measure of confidence

\begin{tabular}{|c|c|c|c|c|c|c|}
\hline \multirow[b]{2}{*}{ Variable } & \multicolumn{3}{|c|}{ Non-confident CEO $(N=7132)$} & \multicolumn{3}{|c|}{ Confident CEO $(N=630)$} \\
\hline & Mean & Median & Std. dev. & Mean & Median & Std. dev. \\
\hline \multicolumn{7}{|l|}{ Dependent variables } \\
\hline Stock return volatility (\%) & 3.03 & 2.67 & 1.49 & $3.14 *$ & 2.71 & 1.64 \\
\hline $\mathrm{R} \& \mathrm{D} /$ Assets $(\%)$ & 3.72 & 0.16 & 7.88 & $4.70 * *$ & $1.46 * * *$ & 7.17 \\
\hline No. of patents & 19.95 & 0.00 & 95.12 & $79.03 * * *$ & $5.00 * * *$ & 216.47 \\
\hline Citation (raw) count & 139.85 & 0.00 & 755.70 & $299.43 * * *$ & $5.00 * * *$ & 1204.02 \\
\hline Qcitation count & 329.18 & 0.00 & 1781.46 & $946.12 * * *$ & $21.47 * * *$ & 3242.62 \\
\hline TTcitation count & 25.65 & 0.00 & 133.54 & $91.96 * * *$ & $2.77 * * *$ & 262.19 \\
\hline Citation count per patent & 2.64 & 0.00 & 6.46 & 2.41 & $0.41 * * *$ & 4.32 \\
\hline Qcitation count per patent & 6.21 & 0.00 & 13.18 & $7.15^{* *}$ & $3.29 * * *$ & 10.02 \\
\hline TTcitation count per patent & 0.52 & 0.00 & 0.99 & $0.70 * * *$ & $0.50 * * *$ & 0.86 \\
\hline \multicolumn{7}{|l|}{ Control variables } \\
\hline TotalMention & 1.41 & 0.00 & 5.50 & $10.95 * * *$ & $5.00 * * *$ & 17.08 \\
\hline Sales & 3132.87 & 974.77 & 6617.85 & $9062.34 * * *$ & $3805.35 * * *$ & 12098.71 \\
\hline PPE/Emp & 134.43 & 44.23 & 382.47 & 141.69 & $60.04 * * *$ & 351.14 \\
\hline Stock return & 0.19 & 0.10 & 0.64 & 0.17 & $0.05 * * *$ & 0.74 \\
\hline Tobin's Q & 2.23 & 1.66 & 1.81 & $2.69 * * *$ & $1.75 * * *$ & 3.28 \\
\hline Sales growth & 0.12 & 0.09 & 0.25 & $0.10 * *$ & $0.07 * * *$ & 0.26 \\
\hline ROA & 0.15 & 0.15 & 0.11 & 0.15 & 0.14 & 0.10 \\
\hline Book leverage & 0.21 & 0.20 & 0.17 & $0.24 * * *$ & $0.22 * * *$ & 0.18 \\
\hline Cash & 0.14 & 0.06 & 0.18 & 0.14 & $0.07 * *$ & 0.17 \\
\hline Institutional holdings & 57.42 & 59.21 & 18.82 & $61.19 * * *$ & $62.55 * * *$ & 15.98 \\
\hline Industry PE & 0.12 & 0.11 & 0.51 & 0.13 & 0.09 & 0.49 \\
\hline \# segments & 1.92 & 1.00 & 1.28 & $2.53 * * *$ & $2.00 * * *$ & 1.83 \\
\hline CEO tenure & 100.58 & 72.00 & 94.85 & 100.67 & 69.00 & 95.54 \\
\hline CEO delta & 737.42 & 211.17 & 1938.95 & $2470.73 * * *$ & $515.94 * * *$ & 5253.43 \\
\hline CEO vega & 88.58 & 35.83 & 177.60 & $265.03 * * *$ & $123.43 * * *$ & 380.02 \\
\hline
\end{tabular}




\section{Table 3. Overconfident CEOs and stock return volatility}

The table presents results of regressions of stock return volatility on CEO overconfidence. Stock return volatility is the standard deviation of daily stock returns over the fiscal year, in percentage. Confident CEO (Options) is an indicator variable that is equal to one for all years after the CEO holds options that are at least $67 \%$ in-the-money. Confident CEO (Press) is an indicator variable that is equal to one when the number of 'confident' articles for a CEO in Factiva exceeds the number of 'cautious' articles. All independent variables are lagged by one year. All continuous independent variables are scaled to have zero mean and standard deviation of one. Definitions of the variables are provided in Appendix A. All regressions include year and industry fixed effects, defined based on 2digit SIC codes. Standard errors are corrected for clustering of observations at the firm level ( $t$-statistics are in parentheses). *, **, and $* * *$ measure significance at the $10 \%, 5 \%$, and $1 \%$ level, respectively.

\begin{tabular}{|c|c|c|c|c|}
\hline \multicolumn{5}{|c|}{ Dependent variable $=$ Stock return volatility $(\%)$} \\
\hline & $(1)$ & $(2)$ & (3) & (4) \\
\hline Confident CEO (Options) & $\begin{array}{l}0.060^{*} \\
(1.78)\end{array}$ & $\begin{array}{l}0.077 \text { ** } \\
(2.12)\end{array}$ & & \\
\hline Confident CEO (Press) & & & $\begin{array}{l}0.199 * * * \\
(2.97)\end{array}$ & $\begin{array}{l}0.203 \text { *** } \\
(3.05)\end{array}$ \\
\hline TotalMention & & & $\begin{array}{l}-0.000 \\
(0.02)\end{array}$ & $\begin{array}{l}0.012 \\
(0.61)\end{array}$ \\
\hline $\log ($ sales $)$ & $\begin{array}{l}-0.364 * * * \\
(17.12)\end{array}$ & $\begin{array}{l}-0.277 * * * \\
(10.25)\end{array}$ & $\begin{array}{l}-0.401 * * * \\
(15.51)\end{array}$ & $\begin{array}{l}-0.349 * * * \\
(11.35)\end{array}$ \\
\hline $\log (\mathrm{PPE} / \mathrm{Emp})$ & $\begin{array}{l}-0.002 \\
(0.07)\end{array}$ & $\begin{array}{l}0.017 \\
(0.66)\end{array}$ & $\begin{array}{l}0.030 \\
(0.98)\end{array}$ & $\begin{array}{l}0.042 \\
(1.36)\end{array}$ \\
\hline Stock return & $\begin{array}{l}-0.005 \\
(0.30)\end{array}$ & $\begin{array}{l}-0.006 \\
(0.40)\end{array}$ & $\begin{array}{l}0.006 \\
(0.36)\end{array}$ & $\begin{array}{l}0.009 \\
(0.54)\end{array}$ \\
\hline Tobin's Q & $\begin{array}{l}0.201 \text { *** } \\
(8.32)\end{array}$ & $\begin{array}{l}0.229 * * * \\
(8.75)\end{array}$ & $\begin{array}{l}0.215^{* * * *} \\
(7.57)\end{array}$ & $\begin{array}{l}0.238 * * * \\
(7.81)\end{array}$ \\
\hline Sales growth & $\begin{array}{l}0.092 * * * \\
(5.92)\end{array}$ & $\begin{array}{l}0.099 * * * \\
(6.51)\end{array}$ & $\begin{array}{l}0.115^{* * * *} \\
(6.52)\end{array}$ & $\begin{array}{l}0.125 * * * \\
(7.05)\end{array}$ \\
\hline ROA & $\begin{array}{l}-0.411^{* * * *} \\
(17.55)\end{array}$ & $\begin{array}{l}-0.413 * * * \\
(17.91)\end{array}$ & $\begin{array}{l}-0.442 * * * \\
(16.58)\end{array}$ & $\begin{array}{l}-0.436^{* * * *} \\
(16.57)\end{array}$ \\
\hline Book leverage & $\begin{array}{l}0.047 * * \\
(2.01)\end{array}$ & $\begin{array}{l}0.045^{* *} \\
(1.98)\end{array}$ & $\begin{array}{l}0.053 * * \\
(2.08)\end{array}$ & $\begin{array}{l}0.052 * * \\
(2.06)\end{array}$ \\
\hline Cash & $\begin{array}{l}0.193 * * * \\
(7.49)\end{array}$ & $\begin{array}{l}0.214 * * * \\
(8.36)\end{array}$ & $\begin{array}{l}0.134 * * * \\
(3.96)\end{array}$ & $\begin{array}{l}0.148 \text { *** } \\
(4.40)\end{array}$ \\
\hline $\log (1+$ tenure $)$ & & $\begin{array}{l}0.014 \\
(0.79)\end{array}$ & & $\begin{array}{l}-0.005 \\
(0.22)\end{array}$ \\
\hline $\log (1+$ delta $)$ & & $\begin{array}{l}-0.053^{* *} \\
(2.08)\end{array}$ & & $\begin{array}{l}-0.074 * * \\
(2.40)\end{array}$ \\
\hline $\log (1+$ vega $)$ & & $\begin{array}{l}-0.090^{* * * *} \\
(3.84)\end{array}$ & & $\begin{array}{l}-0.051^{*} \\
(1.93)\end{array}$ \\
\hline Observations & 8939 & 8939 & 7762 & 7762 \\
\hline Adjusted $R-\mathrm{Sq}$ & 0.553 & 0.557 & 0.540 & 0.542 \\
\hline
\end{tabular}




\section{Table 4. Overconfident CEOs and R\&D expenditures}

The table presents results of regressions of research and development expenditures (R\&D) on CEO overconfidence. The dependent variable is the ratio of $R \& D$ to book assets, expressed as a percentage. Missing values of $R \& D$ are coded with zero. Confident CEO (Options) is an indicator variable that is equal to one for all years after the CEO holds options that are at least 67\% in-the-money. Confident CEO (Press) is an indicator variable that is equal to one when the number of 'confident' articles for a CEO in Factiva exceeds the number of 'cautious' articles. All independent variables are lagged by one year. All continuous independent variables are scaled to have zero mean and standard deviation of one. Definitions of the variables are provided in Appendix A. All regressions include year and industry fixed effects, defined based on 2-digit SIC codes. Standard errors are corrected for clustering of observations at the firm level ( $t$-statistics are in parentheses). *,**, and *** measure significance at the $10 \%, 5 \%$, and $1 \%$ level, respectively.

\begin{tabular}{|c|c|c|c|c|}
\hline \multicolumn{5}{|c|}{ Dependent variable $=\mathrm{R} \& \mathrm{D} /$ Assets $(\%)$} \\
\hline & (1) & (2) & (3) & (4) \\
\hline Confident CEO (Options) & $\begin{array}{l}0.392^{*} \\
(1.71)\end{array}$ & $\begin{array}{l}0.770^{* * * *} \\
(3.27)\end{array}$ & & \\
\hline Confident CEO (Press) & & & $\begin{array}{l}1.011^{* *} \\
(2.45)\end{array}$ & $\begin{array}{l}1.003^{* *} \\
(2.46)\end{array}$ \\
\hline TotalMention & & & $\begin{array}{l}0.155 \\
(1.30)\end{array}$ & $\begin{array}{l}0.182 \\
(1.48)\end{array}$ \\
\hline Log(sales) & $\begin{array}{l}-0.355^{* *} \\
(2.38)\end{array}$ & $\begin{array}{l}-0.553 * * * \\
(3.45)\end{array}$ & $\begin{array}{l}-0.685^{* * * *} \\
(3.56)\end{array}$ & $\begin{array}{l}-0.857 * * * \\
(4.37)\end{array}$ \\
\hline Log(PPE/Emp) & $\begin{array}{l}0.423 * * * \\
(2.76)\end{array}$ & $\begin{array}{l}0.386^{* *} \\
(2.48)\end{array}$ & $\begin{array}{l}0.606^{* * * *} \\
(3.61)\end{array}$ & $\begin{array}{l}0.544 * * * \\
(3.25)\end{array}$ \\
\hline Stock return & $\begin{array}{l}-0.672 * * * \\
(5.54)\end{array}$ & $\begin{array}{l}-0.603 * * * \\
(5.03)\end{array}$ & $\begin{array}{l}-0.623 * * * \\
(4.81)\end{array}$ & $\begin{array}{l}-0.578^{* * * *} \\
(4.49)\end{array}$ \\
\hline Tobin's Q & $\begin{array}{l}1.229 * * * \\
(4.86)\end{array}$ & $\begin{array}{l}1.264 * * * \\
(4.76)\end{array}$ & $\begin{array}{l}1.300 * * * \\
(4.59)\end{array}$ & $\begin{array}{l}1.355^{* * * *} \\
(4.64)\end{array}$ \\
\hline Sales growth & $\begin{array}{l}0.074 \\
(0.39)\end{array}$ & $\begin{array}{l}0.113 \\
(0.60)\end{array}$ & $\begin{array}{l}-0.043 \\
(0.24)\end{array}$ & $\begin{array}{l}0.026 \\
(0.15)\end{array}$ \\
\hline ROA & $\begin{array}{l}-2.201 * * * \\
(6.36)\end{array}$ & $\begin{array}{l}-2.147 * * * \\
(6.31)\end{array}$ & $\begin{array}{l}-2.241 * * * \\
(5.83)\end{array}$ & $\begin{array}{l}-2.176^{* * *} \\
(5.73)\end{array}$ \\
\hline Book leverage & $\begin{array}{l}-0.593 * * * \\
(4.38)\end{array}$ & $\begin{array}{l}-0.619 * * * \\
(4.59)\end{array}$ & $\begin{array}{l}-0.478 * * * \\
(3.25)\end{array}$ & $\begin{array}{l}-0.544 * * * \\
(3.68)\end{array}$ \\
\hline Cash & $\begin{array}{l}2.126^{* * * *} \\
(9.62)\end{array}$ & $\begin{array}{l}2.057 * * * \\
(9.35)\end{array}$ & $\begin{array}{l}1.789 * * * \\
(7.68)\end{array}$ & $\begin{array}{l}1.764 * * * \\
(7.76)\end{array}$ \\
\hline $\log (1+$ tenure $)$ & & $\begin{array}{l}-0.126 \\
(1.17)\end{array}$ & & $\begin{array}{l}-0.019 \\
(0.15)\end{array}$ \\
\hline $\log (1+$ delta $)$ & & $\begin{array}{l}-0.594 * * * \\
(4.04)\end{array}$ & & $\begin{array}{l}-0.493 * * * \\
(3.37)\end{array}$ \\
\hline $\log (1+$ vega $)$ & & $\begin{array}{l}0.741 * * * \\
(6.11)\end{array}$ & & $\begin{array}{l}0.781 \text { *** } \\
(5.82)\end{array}$ \\
\hline Observations & 8939 & 8939 & 7762 & 7762 \\
\hline Adjusted $R$-Sq & 0.466 & 0.471 & 0.454 & 0.462 \\
\hline
\end{tabular}




\section{Table 5. Overconfident CEOs and patent counts}

The table presents results of regressions of patent counts on CEO overconfidence. Patent is the number of patents applied for during the year. Confident CEO (Options) is an indicator variable that is equal to one for all years after the CEO holds options that are at least 67\% in-the-money. Confident CEO (Press) is an indicator variable that is equal to one when the number of 'confident' articles for a CEO in Factiva exceeds the number of 'cautious' articles. All independent variables are lagged by one year. All continuous independent variables are scaled to have zero mean and standard deviation of one. Definitions of the variables are provided in Appendix A. All regressions include year and industry fixed effects, defined based on 2-digit SIC codes. Standard errors are corrected for clustering of observations at the firm level ( $t$-statistics are in parentheses). *, **, and $* * *$ measure significance at the $10 \%, 5 \%$, and $1 \%$ level, respectively. ${ }^{+}$indicates $p$-value of $10.1 \%$.

\begin{tabular}{|c|c|c|c|c|c|c|}
\hline \multicolumn{7}{|c|}{ Dependent variable $=\log (1+$ patent $)$} \\
\hline & $(1)$ & $(2)$ & $(3)$ & $(4)$ & (5) & (6) \\
\hline Confident CEO (Options) & $\begin{array}{l}0.093^{*} \\
(1.93)\end{array}$ & $\begin{array}{l}0.093^{*} \\
(1.90)\end{array}$ & $\begin{array}{l}0.111^{* *} \\
(2.09)\end{array}$ & & & \\
\hline Confident CEO (Press) & & & & $\begin{array}{l}0.285^{* * * *} \\
(2.59)\end{array}$ & $\begin{array}{l}0.281^{* *} \\
(2.56)\end{array}$ & $\begin{array}{l}0.272 * * \\
(2.48)\end{array}$ \\
\hline TotalMention & & & & $\begin{array}{l}0.189 * * * \\
(4.80)\end{array}$ & $\begin{array}{l}0.183 * * * \\
(4.64)\end{array}$ & $\begin{array}{l}0.169 * * * \\
(4.10)\end{array}$ \\
\hline $\log ($ sales $)$ & $\begin{array}{l}0.732 * * * \\
(16.23)\end{array}$ & $\begin{array}{l}0.761 * * * \\
(15.79)\end{array}$ & $\begin{array}{l}0.640 \text { *** } \\
(12.58)\end{array}$ & $\begin{array}{l}0.582 * * * \\
(12.83)\end{array}$ & $\begin{array}{l}0.602 * * * \\
(12.54)\end{array}$ & $\begin{array}{l}0.552 * * * \\
(11.17)\end{array}$ \\
\hline Log(PPE/Emp) & $\begin{array}{l}0.244 * * * \\
(4.76)\end{array}$ & $\begin{array}{l}0.251 * * * \\
(4.88)\end{array}$ & $\begin{array}{l}0.218 * * * \\
(4.23)\end{array}$ & $\begin{array}{l}0.259 * * * \\
(4.49)\end{array}$ & $\begin{array}{l}0.265 * * * \\
(4.60)\end{array}$ & $\begin{array}{l}0.245 * * * \\
(4.23)\end{array}$ \\
\hline Stock return & & $\begin{array}{l}0.061 \text { *** } \\
(5.32)\end{array}$ & $\begin{array}{l}0.052 * * * \\
(4.27)\end{array}$ & & $\begin{array}{l}0.057 * * * \\
(4.87)\end{array}$ & $\begin{array}{l}0.059 * * * \\
(4.57)\end{array}$ \\
\hline Institutional holdings & & $\begin{array}{l}-0.079 * * * \\
(2.62)\end{array}$ & $\begin{array}{l}-0.113 * * * \\
(3.77)\end{array}$ & & $\begin{array}{l}-0.040 \\
(1.33)\end{array}$ & $\begin{array}{l}-0.077 \text { *** } \\
(2.59)\end{array}$ \\
\hline $\log (1+$ tenure $)$ & & & $\begin{array}{l}-0.051 * * \\
(2.08)\end{array}$ & & & $\begin{array}{l}-0.017 \\
(0.66)\end{array}$ \\
\hline $\log (1+$ delta $)$ & & & $\begin{array}{l}0.014 \\
(0.39)\end{array}$ & & & $\begin{array}{l}-0.013 \\
(0.39)\end{array}$ \\
\hline $\log (1+$ vega $)$ & & & $\begin{array}{l}0.218^{* * * *} \\
(5.57)\end{array}$ & & & $\begin{array}{l}0.164 * * * \\
(4.33)\end{array}$ \\
\hline Observations & 8939 & 8939 & 8939 & 7762 & 7762 & 7762 \\
\hline Adjusted $R-\mathrm{Sq}$ & 0.494 & 0.497 & 0.507 & 0.531 & 0.533 & 0.539 \\
\hline
\end{tabular}




\section{Table 6. Overconfident CEOs and patent citations}

The table presents results of regressions of patent citations on CEO overconfidence. Qcitation count (TTcitation count) is the total adjusted number of citations to all the patents applied for during the year. To adjust for truncation bias, for Qcitation count the raw citation count number for each patent is multiplied by the weighting index of Hall, Jaffe, and Trajtenberg (2001, 2005); for TTcitation count the raw citation count number for each patent is divided by the average citation count of all patents in the same technology class and applied for in the same year. Then the adjusted citation count of each patent belonging to a firmyear is aggregated up to the firm-year level. Confident CEO (Options) is an indicator variable that is equal to one for all years after the CEO holds options that are at least $67 \%$ in-the-money. Confident CEO (Press) is an indicator variable that is equal to one when the number of 'confident' articles for a CEO in Factiva exceeds the number of 'cautious' articles. All independent variables are lagged by one year. All continuous independent variables are scaled to have zero mean and standard deviation of one. Definitions of the variables are provided in Appendix A. All regressions include year and industry fixed effects, defined based on 2 -digit SIC codes. Standard errors are corrected for clustering of observations at the firm level ( $t$-statistics are in parentheses). *, **, and *** measure significance at the $10 \%, 5 \%$, and $1 \%$ level, respectively.

\begin{tabular}{|c|c|c|c|c|c|c|c|c|c|c|c|c|}
\hline & \multicolumn{12}{|c|}{ Dependent variable $=$} \\
\hline & \multicolumn{6}{|c|}{$\log (1+Q$ citation count $)$} & \multicolumn{6}{|c|}{$\log (1+\mathrm{TT}$ citation count $)$} \\
\hline & $(1)$ & (2) & (3) & (4) & $(5)$ & (6) & (1) & (2) & (3) & (4) & $(5)$ & (6) \\
\hline Confident CEO (Options) & $\begin{array}{l}0.165^{* * *} \\
(2.14)\end{array}$ & $\begin{array}{l}0.151 * \\
(1.94)\end{array}$ & $\begin{array}{l}0.181 * * \\
(2.11)\end{array}$ & & & & $\begin{array}{l}0.110 * * \\
(2.16)\end{array}$ & $\begin{array}{l}0.107 * * \\
(2.06)\end{array}$ & $\begin{array}{l}0.121 * * \\
(2.16)\end{array}$ & & & \\
\hline Confident CEO (Press) & & & & $\begin{array}{l}0.425^{* * * *} \\
(2.64)\end{array}$ & $\begin{array}{l}0.418^{* * * *} \\
(2.61)\end{array}$ & $\begin{array}{l}0.404 * * \\
(2.52)\end{array}$ & & & & $\begin{array}{l}0.260^{* * *} \\
(2.23)\end{array}$ & $\begin{array}{l}0.255^{* * *} \\
(2.20)\end{array}$ & $\begin{array}{l}0.245^{* *} \\
(2.11)\end{array}$ \\
\hline TotalMention & & & & $\begin{array}{l}0.243 * * * \\
(4.96)\end{array}$ & $\begin{array}{l}0.239 * * * \\
(4.86)\end{array}$ & $\begin{array}{l}0.218 * * * \\
(4.16)\end{array}$ & & & & $\begin{array}{l}0.196^{* * * *} \\
(5.00)\end{array}$ & $\begin{array}{l}0.189 * * * \\
(4.84)\end{array}$ & $\begin{array}{l}0.174 * * * \\
(4.29)\end{array}$ \\
\hline Log(sales) & $\begin{array}{l}0.976^{* * * *} \\
(14.95)\end{array}$ & $\begin{array}{l}1.008 * * * \\
(14.58)\end{array}$ & $\begin{array}{l}0.821 * * * \\
(10.71)\end{array}$ & $\begin{array}{l}0.776^{* * * *} \\
(11.13)\end{array}$ & $\begin{array}{l}0.793 * * * \\
(10.90)\end{array}$ & $\begin{array}{l}0.718 * * * \\
(9.30)\end{array}$ & $\begin{array}{l}0.733^{* * * *} \\
(15.23)\end{array}$ & $\begin{array}{l}0.764 * * * \\
(14.88)\end{array}$ & $\begin{array}{l}0.637 * * * \\
(11.80)\end{array}$ & $\begin{array}{l}0.587 * * * \\
(11.95)\end{array}$ & $\begin{array}{l}0.608 * * * \\
(11.71)\end{array}$ & $\begin{array}{l}0.554 * * * \\
(10.38)\end{array}$ \\
\hline Log(PPE/Emp) & $\begin{array}{l}0.385^{* * *} * \\
(4.76)\end{array}$ & $\begin{array}{l}0.395^{* * *} \\
(4.87)\end{array}$ & $\begin{array}{l}0.343^{* * *} \\
(4.24)\end{array}$ & $\begin{array}{l}0.403 * * * \\
(4.34)\end{array}$ & $\begin{array}{l}0.411 * * * \\
(4.42)\end{array}$ & $\begin{array}{l}0.381 * * * \\
(4.08)\end{array}$ & $\begin{array}{l}0.260 * * * \\
(4.63)\end{array}$ & $\begin{array}{l}0.268 * * * \\
(4.76)\end{array}$ & $\begin{array}{l}0.233 * * * \\
(4.13)\end{array}$ & $\begin{array}{l}0.274 * * * \\
(4.22)\end{array}$ & $\begin{array}{l}0.281 * * * \\
(4.33)\end{array}$ & $\begin{array}{l}0.260 * * * \\
(3.98)\end{array}$ \\
\hline Stock return & & $\begin{array}{l}0.110 * * * \\
(5.01)\end{array}$ & $\begin{array}{l}0.098 * * * \\
(4.36)\end{array}$ & & $\begin{array}{l}0.112 * * * \\
(4.94)\end{array}$ & $\begin{array}{l}0.113^{* * * *} \\
(4.70)\end{array}$ & & $\begin{array}{l}0.074 * * * \\
(5.51)\end{array}$ & $\begin{array}{l}0.061 \text { *** } \\
(4.36)\end{array}$ & & $\begin{array}{l}0.076^{* * * *} \\
(5.25)\end{array}$ & $\begin{array}{l}0.074 * * * \\
(4.74)\end{array}$ \\
\hline Institutional holdings & & $\begin{array}{l}-0.079 * \\
(1.67)\end{array}$ & $\begin{array}{l}-0.133 * * * \\
(2.84)\end{array}$ & & $\begin{array}{l}-0.022 \\
(0.45)\end{array}$ & $\begin{array}{l}-0.076 \\
(1.60)\end{array}$ & & $\begin{array}{l}-0.082^{* * * *} \\
(2.61)\end{array}$ & $\begin{array}{l}-0.115^{* * *} \\
(3.68)\end{array}$ & & $\begin{array}{l}-0.038 \\
(1.21)\end{array}$ & $\begin{array}{l}-0.073 * * \\
(2.33)\end{array}$ \\
\hline $\log (1+$ tenure $)$ & & & $\begin{array}{l}-0.071 * \\
(1.80)\end{array}$ & & & $\begin{array}{l}-0.026 \\
(0.62)\end{array}$ & & & $\begin{array}{l}-0.064 * * \\
(2.46)\end{array}$ & & & $\begin{array}{l}-0.026 \\
(0.93)\end{array}$ \\
\hline $\log (1+$ delta $)$ & & & $\begin{array}{l}0.010 \\
(0.17)\end{array}$ & & & $\begin{array}{l}-0.016 \\
(0.29)\end{array}$ & & & $\begin{array}{l}0.035 \\
(0.91)\end{array}$ & & & $\begin{array}{l}0.005 \\
(0.13)\end{array}$ \\
\hline $\log (1+$ vega $)$ & & & $\begin{array}{l}0.349 * * * \\
(5.50)\end{array}$ & & & $\begin{array}{l}0.242 * * * \\
(3.95)\end{array}$ & & & $\begin{array}{l}0.211 * * * \\
(5.22)\end{array}$ & & & $\begin{array}{l}0.155^{* * * *} \\
(3.94)\end{array}$ \\
\hline Observations & 8939 & 8939 & 8939 & 7762 & 7762 & 7762 & 8939 & 8939 & 8939 & 7762 & 7762 & 7762 \\
\hline Adjusted $R-\mathrm{Sq}$ & 0.472 & 0.474 & 0.483 & 0.504 & 0.506 & 0.511 & 0.457 & 0.461 & 0.471 & 0.490 & 0.492 & 0.497 \\
\hline
\end{tabular}




\section{Table 7. Effect of industry innovativeness}

The table presents results from regressions of patent count and patent citations on CEO overconfidence, where firms are classified based on whether they belong to an innovative industry or not. An innovative industry is one where the average Qcitation count per patent for the industry is greater than the median Qcitation count per patent across all industries. Innovative industry is lagged by one year. Confident CEO (Options) is an indicator variable that is equal to one for all years after the CEO holds options that are at least $67 \%$ in-the-money. Confident CEO (Press) is an indicator variable that is equal to one when the number of

'confident' articles for a CEO in Factiva exceeds the number of 'cautious' articles. Only the coefficients and $t$-statistics associated with the confidence variables are shown. Each cell in the table is from one regression of the dependent variable on either Confident CEO (Options) or Confident CEO (Press), control variables, year and industry fixed effects, defined based on the 2-digit SIC codes. The control variables are Log(sales), Log(PPE/Emp), stock returns over the fiscal year, institutional holdings, $\log (1+$ tenure $), \log (1+$ delta $)$, and $\log (1+\mathrm{vega})$. When using the press-based overconfidence measure, TotalMention, the number of news articles, is added as an additional control variable. All control variables are lagged by one year. Definitions of the variables are provided in Appendix A.

Standard errors are corrected for clustering of observations at the firm level ( $t$-statistics are in parentheses). *,**, and $* * *$ measure significance at the $10 \%, 5 \%$, and $1 \%$ level, respectively.

\begin{tabular}{|c|c|c|c|c|c|c|c|c|}
\hline & \multicolumn{2}{|c|}{ No. of observations } & \multicolumn{2}{|c|}{$\log (1+$ patent $)$} & \multicolumn{2}{|c|}{$\begin{array}{c}\text { Dependent variable }= \\
\log (1+\text { Qcitation count })\end{array}$} & \multicolumn{2}{|c|}{$\log (1+$ TTcitation count $)$} \\
\hline & $\begin{array}{l}\text { Innovative } \\
\text { Ind. }\end{array}$ & $\begin{array}{l}\text { Non-Inno. } \\
\text { Ind. }\end{array}$ & $\begin{array}{l}\text { Innovative } \\
\text { Ind. } \\
(1)\end{array}$ & $\begin{array}{l}\text { Non-Inno. } \\
\text { Ind. } \\
(2)\end{array}$ & $\begin{array}{l}\text { Innovative } \\
\text { Ind. } \\
\text { (1) }\end{array}$ & $\begin{array}{l}\text { Non-Inno. } \\
\text { Ind. } \\
(2)\end{array}$ & $\begin{array}{l}\text { Innovative } \\
\text { Ind. } \\
\text { (1) }\end{array}$ & $\begin{array}{l}\text { Non-Inno. } \\
\text { Ind. } \\
(2)\end{array}$ \\
\hline Confident CEO (Options) & 6055 & 2884 & $\begin{array}{l}0.156 * * \\
(2.43)\end{array}$ & $\begin{array}{l}0.024 \\
(0.29)\end{array}$ & $\begin{array}{l}0.278 * * * \\
(2.65)\end{array}$ & $\begin{array}{l}-0.010 \\
(0.08)\end{array}$ & $\begin{array}{l}0.169 * * \\
(2.44)\end{array}$ & $\begin{array}{l}0.030 \\
(0.39)\end{array}$ \\
\hline Confident CEO (Press) & 5172 & 2590 & $\begin{array}{l}0.404 * * * \\
(3.02)\end{array}$ & $\begin{array}{l}-0.061 \\
(0.41)\end{array}$ & $\begin{array}{l}0.584 * * * \\
(2.96)\end{array}$ & $\begin{array}{l}-0.046 \\
(0.20)\end{array}$ & $\begin{array}{l}0.378 * * * \\
(2.61)\end{array}$ & $\begin{array}{l}-0.093 \\
(0.62)\end{array}$ \\
\hline
\end{tabular}




\section{Table 8. Overconfident CEOs and citations per patent}

The table presents results of regressions of average citations per patent on CEO overconfidence. Qcitation count (TTcitation count) per patent is the adjusted number of citations per patent applied for during the year. Confident CEO (Options) is an indicator variable that is equal to one for all years after the CEO holds options that are at least $67 \%$ in-the-money. Confident CEO (Press) is an indicator variable that is equal to one when the number of 'confident' articles for a CEO in Factiva exceeds the number of 'cautious' articles. Only the coefficients and $t$ statistics associated with the confidence variables are shown. Each cell in the table is from one regression of the dependent variable on either Confident CEO (Options) or Confident CEO (Press), control variables, year and industry fixed effects, defined based on the 2-digit SIC codes. The control variables are $\log ($ sales $), \log (\mathrm{PPE} / \mathrm{Emp})$, stock returns over the fiscal year, institutional holdings, $\log (1+$ tenure $), \log (1+$ delta $)$, and $\log (1+$ vega $)$. When using the press-based overconfidence measure, TotalMention, the number of news articles, is added as an additional control variable. All control variables are lagged by one year. Definitions of the variables are provided in Appendix A. Standard errors are corrected for clustering of observations at the firm level ( $t$-statistics are in parentheses). *, **, and $* * *$ measure significance at the $10 \%, 5 \%$, and $1 \%$ level, respectively.

\begin{tabular}{|c|c|c|c|c|c|c|}
\hline & \multicolumn{6}{|c|}{ Dependent variable $=$} \\
\hline & \multicolumn{3}{|c|}{$\log (1+$ Qcitation count per patent $)$} & \multicolumn{3}{|c|}{$\log (1+$ TTcitation count per patent $)$} \\
\hline & $\begin{array}{l}\text { Full } \\
\text { Sample } \\
\text { (1) }\end{array}$ & $\begin{array}{l}\text { Innovative } \\
\text { Ind. } \\
\text { (2) }\end{array}$ & $\begin{array}{l}\text { Non-Inno. } \\
\text { Ind. } \\
\text { (3) }\end{array}$ & $\begin{array}{l}\text { Full } \\
\text { Sample } \\
\text { (1) }\end{array}$ & $\begin{array}{l}\text { Innovative } \\
\text { Ind. } \\
\text { (2) }\end{array}$ & $\begin{array}{l}\text { Non-Inno } \\
\text { Ind. } \\
\text { (3) }\end{array}$ \\
\hline Confident CEO (Options) & $\begin{array}{l}0.069 * \\
(1.65)\end{array}$ & $\begin{array}{l}0.130 * * \\
(2.53)\end{array}$ & $\begin{array}{l}-0.050 \\
(0.83)\end{array}$ & $\begin{array}{l}0.014 \\
(0.98)\end{array}$ & $\begin{array}{l}0.034^{*} \\
(1.95)\end{array}$ & $\begin{array}{l}-0.024 \\
(1.23)\end{array}$ \\
\hline Confident CEO (Press) & $\begin{array}{l}0.159^{* *} \\
(2.45)\end{array}$ & $\begin{array}{l}0.190^{* *} \\
(2.39)\end{array}$ & $\begin{array}{l}0.079 \\
(0.79)\end{array}$ & $\begin{array}{l}0.047^{*} \\
(1.93)\end{array}$ & $\begin{array}{l}0.053^{*} \\
(1.77)\end{array}$ & $\begin{array}{l}0.025 \\
(0.68)\end{array}$ \\
\hline
\end{tabular}




\section{Table 9. Different degrees of overconfidence}

The table shows results from regressions of various dependent variables on indicators of different levels of CEO overconfidence and on other control variables. Only coefficients and $t$-statistics for the Confident CEO (Low, Med, and High) variables are shown. Regressions are performed separately on the full sample and firms in innovative industries. Each line in the table is from one regression of the dependent variable on Confident CEO (Low), Confident CEO (Med), Confident CEO (High), control variables, year and industry fixed effects. Confident CEO (Low) is equal to one for all years after the CEO holds options that are at least $67 \%$ in-the-money but less than $130 \%$ in-the-money, and zero otherwise. Confident CEO (Med) is equal to one for all years after the CEO holds options that are at least $130 \%$ in-the-money but less than $250 \%$ in-the-money, and is zero otherwise. Confident CEO (High) is equal to one for all years after the CEO holds options that are at least $250 \%$ in-the-money, and is zero otherwise. The control variables for the stock return volatility and R\&D/Assets regressions are given in Table 3 , model (2). The control variables for the patent and citation regressions are given in Table 5, model (3). Standard errors are corrected for clustering of observations at the firm level ( $t$-statistics are in parentheses). *, **, and *** measure significance at the $10 \%, 5 \%$, and $1 \%$ level, respectively.

\begin{tabular}{|c|c|c|c|}
\hline \multirow[b]{2}{*}{ Sample } & \multicolumn{3}{|c|}{ Coefficients on } \\
\hline & $\begin{array}{l}\text { Confident CEO } \\
\text { (Low) }\end{array}$ & $\begin{array}{l}\text { Confident CEO } \\
\text { (Med) }\end{array}$ & $\begin{array}{l}\text { Confident CEO } \\
\text { (High) }\end{array}$ \\
\hline \multicolumn{4}{|c|}{ Dependent variable $=$ Stock return volatility $(\%)$} \\
\hline Full Sample & $\begin{array}{l}-0.063 \\
(1.57)\end{array}$ & $\begin{array}{l}0.115^{* *} \\
(2.37)\end{array}$ & $\begin{array}{l}0.278 * * * \\
(5.21)\end{array}$ \\
\hline \multicolumn{4}{|c|}{ Dependent variable $=R \& D /$ Assets $(\%)$} \\
\hline Full Sample & $\begin{array}{l}0.804 * * * \\
(3.41)\end{array}$ & $\begin{array}{l}1.292 * * * \\
(3.28)\end{array}$ & $\begin{array}{l}0.010 \\
(0.03)\end{array}$ \\
\hline \multicolumn{4}{|c|}{ Dependent variable $=\log (1+$ patent $)$} \\
\hline Full Sample & $\begin{array}{l}0.096 \\
(1.60)\end{array}$ & $\begin{array}{l}0.039 \\
(0.56)\end{array}$ & $\begin{array}{l}0.225 * * * \\
(2.91)\end{array}$ \\
\hline Innovative Ind. & $\begin{array}{l}0.162^{* *} \\
(2.21)\end{array}$ & $\begin{array}{l}0.061 \\
(0.72)\end{array}$ & $\begin{array}{l}0.256 * * * \\
(2.74)\end{array}$ \\
\hline \multicolumn{4}{|c|}{ Dependent variable $=\log (1+$ Qcitation count $)$} \\
\hline Full Sample & $\begin{array}{l}0.178^{*} \\
(1.84)\end{array}$ & $\begin{array}{l}0.072 \\
(0.64)\end{array}$ & $\begin{array}{l}0.324 * * * \\
(2.59)\end{array}$ \\
\hline Innovative Ind. & $\begin{array}{l}0.312 * * * \\
(2.60)\end{array}$ & $\begin{array}{l}0.127 \\
(0.94)\end{array}$ & $\begin{array}{l}0.399 * * * \\
(2.63)\end{array}$ \\
\hline \multicolumn{4}{|c|}{ Dependent variable $=\log (1+$ TT citation count $)$} \\
\hline Full Sample & $\begin{array}{l}0.109^{*} \\
(1.73)\end{array}$ & $\begin{array}{l}0.042 \\
(0.58)\end{array}$ & $\begin{array}{l}0.239 * * * \\
(2.88)\end{array}$ \\
\hline Innovative Ind. & $\begin{array}{l}0.178^{* *} \\
(2.25)\end{array}$ & $\begin{array}{l}0.053 \\
(0.60)\end{array}$ & $\begin{array}{l}0.288^{* * * *} \\
(2.82)\end{array}$ \\
\hline
\end{tabular}




\section{Table 10. Deleting firms with short-tenured CEOs}

The table examines the effect of restricting the sample to CEOs with tenure of some minimum length. Columns (1) and (2) repeat results from previous tables in which CEOs of all tenure are included. Columns (3) and (4) restrict the sample to CEOs with tenure greater than 4 years. Columns (5) and (6) restrict the sample to CEOs with tenure greater than 6 years. Only the coefficients and $t$-statistics associated with the confidence variables are shown. Regressions are performed separately on the full sample and firms in innovative industries. Each cell in the table is from one regression of the dependent variable on either Confident CEO (Options) or Confident CEO (Press), control variables, year and industry fixed effects. The control variables for the stock return volatility and R\&D/Assets regressions are given in Table 3, model (2). The control variables for the patent and citation regressions are given in Table 5, model (3). Standard errors are corrected for clustering of observations at the firm level ( $t$-statistics are in parentheses). ${ }^{*}, *$, and $* * *$ measure significance at the $10 \%, 5 \%$, and $1 \%$ level, respectively.

\begin{tabular}{|c|c|c|c|c|c|c|}
\hline \multirow[b]{2}{*}{ Sample } & \multicolumn{2}{|c|}{$\underline{\text { All CEOs }}$} & \multicolumn{2}{|c|}{$\underline{\text { CEOs (tenure }>4 \mathrm{yrs} \text { ) }}$} & \multicolumn{2}{|c|}{$\underline{\text { CEOs (tenure }>6 \text { yrs) }}$} \\
\hline & $\begin{array}{l}\text { Confident } \\
\text { CEO } \\
\text { (Options) } \\
\text { (1) }\end{array}$ & $\begin{array}{l}\text { Confident } \\
\text { CEO } \\
\text { (press) } \\
(2)\end{array}$ & $\begin{array}{l}\text { Confident } \\
\text { CEO } \\
\text { (Options) } \\
\text { (3) }\end{array}$ & $\begin{array}{l}\text { Confident } \\
\text { CEO } \\
\text { (press) } \\
(4)\end{array}$ & $\begin{array}{l}\text { Confident } \\
\text { CEO } \\
\text { (Options) } \\
(5)\end{array}$ & $\begin{array}{l}\text { Confident } \\
\text { CEO } \\
\text { (press) } \\
(6)\end{array}$ \\
\hline \multicolumn{7}{|c|}{ Dependent variable $=$ Stock return volatility $(\%)$} \\
\hline Full Sample & $\begin{array}{l}0.077 * * \\
(2.12)\end{array}$ & $\begin{array}{l}0.203 * * * \\
(3.05)\end{array}$ & $\begin{array}{l}0.069 \\
(1.37)\end{array}$ & $\begin{array}{l}0.194 * * \\
(2.49)\end{array}$ & $\begin{array}{l}0.102 * \\
(1.83)\end{array}$ & $\begin{array}{l}0.205^{* *} \\
(2.30)\end{array}$ \\
\hline \multicolumn{7}{|c|}{ Dependent variable $=R \& D /$ Assets $(\%)$} \\
\hline Full Sample & $\begin{array}{l}0.770 * * * \\
(3.27)\end{array}$ & $\begin{array}{l}1.003 * * \\
(2.46)\end{array}$ & $\begin{array}{l}0.909^{* * *} \\
(2.98)\end{array}$ & $\begin{array}{l}1.065^{* *} \\
(2.03)\end{array}$ & $\begin{array}{l}0.957 * * * \\
(2.81)\end{array}$ & $\begin{array}{l}1.118^{* *} \\
(1.98)\end{array}$ \\
\hline \multicolumn{7}{|c|}{ Dependent variable $=\log (1+$ patent $)$} \\
\hline Full Sample & $\begin{array}{l}0.111 * * \\
(2.09)\end{array}$ & $\begin{array}{l}0.272 * * \\
(2.48)\end{array}$ & $\begin{array}{l}0.156^{* *} \\
(2.33)\end{array}$ & $\begin{array}{l}0.349 * * \\
(2.56)\end{array}$ & $\begin{array}{l}0.166^{* *} \\
(2.20)\end{array}$ & $\begin{array}{l}0.378 * * \\
(2.58)\end{array}$ \\
\hline Innovative Ind. & $\begin{array}{l}0.156^{* *} \\
(2.43)\end{array}$ & $\begin{array}{l}0.404 * * * \\
(3.02)\end{array}$ & $\begin{array}{l}0.228^{* * * *} \\
(2.75)\end{array}$ & $\begin{array}{l}0.461 * * * \\
(2.86)\end{array}$ & $\begin{array}{l}0.257 \text { *** } \\
(2.78)\end{array}$ & $\begin{array}{l}0.502 * * * \\
(2.89)\end{array}$ \\
\hline \multicolumn{7}{|c|}{ Dependent variable $=\log (1+Q$ citation count $)$} \\
\hline Full Sample & $\begin{array}{l}0.181 * * \\
(2.11)\end{array}$ & $\begin{array}{l}0.404 * * \\
(2.52)\end{array}$ & $\begin{array}{l}0.232 * * \\
(2.11)\end{array}$ & $\begin{array}{l}0.507 * * \\
(2.53)\end{array}$ & $\begin{array}{l}0.246^{*} \\
(1.93)\end{array}$ & $\begin{array}{l}0.523 * * \\
(2.41)\end{array}$ \\
\hline Innovative Ind. & $\begin{array}{l}0.278 * * * \\
(2.65)\end{array}$ & $\begin{array}{l}0.584 * * * \\
(2.96)\end{array}$ & $\begin{array}{l}0.394 * * * \\
(2.85)\end{array}$ & $\begin{array}{l}0.627 * * * \\
(2.64)\end{array}$ & $\begin{array}{l}0.428 * * * \\
(2.72)\end{array}$ & $\begin{array}{l}0.663 * * \\
(2.57)\end{array}$ \\
\hline \multicolumn{7}{|c|}{ Dependent variable $=\log (1+$ TTcitation count $)$} \\
\hline Full Sample & $\begin{array}{l}0.121 * * \\
(2.16)\end{array}$ & $\begin{array}{l}0.245^{* *} \\
(2.11)\end{array}$ & $\begin{array}{l}0.164 * * \\
(2.37)\end{array}$ & $\begin{array}{l}0.302 * * \\
(2.13)\end{array}$ & $\begin{array}{l}0.185^{* *} \\
(2.37)\end{array}$ & $\begin{array}{l}0.327 * * \\
(2.14)\end{array}$ \\
\hline Innovative Ind. & $\begin{array}{l}0.169 * * \\
(2.44)\end{array}$ & $\begin{array}{l}0.378 * * * \\
(2.61)\end{array}$ & $\begin{array}{l}0.243 \text { **** } \\
(2.76)\end{array}$ & $\begin{array}{l}0.378^{* *} \\
(2.24)\end{array}$ & $\begin{array}{l}0.272 * * * \\
(2.77)\end{array}$ & $\begin{array}{l}0.414 * * \\
(2.26)\end{array}$ \\
\hline
\end{tabular}




\section{Table 11. Effectiveness of innovative activity}

The table presents results from regressions that test the effect of CEO overconfidence on the effectiveness of innovation for given research and development (R\&D) expenditure. Confident CEO (Options) is an indicator variable that is equal to one for all years after the CEO holds options that are at least $67 \%$ in-themoney. Confident CEO (Press) is equal to one when the number of 'confident' articles for a CEO in Factiva exceeds the number of 'cautious' articles. Only the coefficients and $t$-statistics associated with the confidence variables and $\log (1+\mathrm{R} \& \mathrm{D} / \mathrm{Asset})$ are shown. Each column in the table is from one regression of the dependent variable on either Confident CEO (Options) or Confident CEO (Press), Log(1+R\&D/Asset), control variables, year and industry fixed effects, defined based on the 2-digit SIC codes. The control variables are $\log ($ sales $), \log (\mathrm{PPE} / \mathrm{Emp})$, stock returns over the fiscal year, institutional holdings, Log(1+tenure), $\log (1+$ delta $)$, and $\log (1+$ vega $)$. When using the press-based overconfidence measure, TotalMention, the number of news articles, is added as an additional control variable. All independent variables are lagged by one year. All continuous independent variables are scaled to have zero mean and standard deviation of one. Definitions of the variables are provided in Appendix A. Standard errors are corrected for clustering of observations at the firm level ( $t$-statistics are in parentheses). *,**, and $* * *$ measure significance at the $10 \%, 5 \%$, and $1 \%$ level, respectively.

\begin{tabular}{|c|c|c|c|c|c|c|c|c|c|c|c|c|}
\hline & \multicolumn{12}{|c|}{ Dependent variable = } \\
\hline & $\begin{array}{l}\text { Innovative } \\
(1)\end{array}$ & $\begin{array}{l}\text { Ind. } \\
(2)\end{array}$ & $\begin{array}{l}\text { Non-Inno } \\
(3)\end{array}$ & $\begin{array}{l}\text { vative Ind. } \\
(4)\end{array}$ & $\begin{array}{l}\text { Innovative } \\
(1)\end{array}$ & $\begin{array}{l}\text { Ind. } \\
(2)\end{array}$ & $\begin{array}{l}\text { Non-Inno } \\
(3)\end{array}$ & $\begin{array}{l}\text { vative Ind. } \\
\text { (4) }\end{array}$ & $\begin{array}{l}\text { Innovative } \\
(1)\end{array}$ & $\begin{array}{l}\text { Ind. } \\
(2)\end{array}$ & $\begin{array}{l}\text { Non-Inno } \\
(3)\end{array}$ & $\begin{array}{l}\text { vative Ind. } \\
\text { (4) }\end{array}$ \\
\hline Confident CEO (Options) & $\begin{array}{l}0.114 * \\
(1.86)\end{array}$ & & $\begin{array}{l}-0.040 \\
(0.52)\end{array}$ & & $\begin{array}{l}0.203 * * \\
(2.04)\end{array}$ & & $\begin{array}{l}-0.107 \\
(0.87)\end{array}$ & & $\begin{array}{l}0.123^{*} \\
(1.87)\end{array}$ & & $\begin{array}{l}-0.021 \\
(0.27)\end{array}$ & \\
\hline Confident CEO (Press) & & $\begin{array}{l}0.274 * * \\
(2.27)\end{array}$ & & $\begin{array}{l}-0.058 \\
(0.38)\end{array}$ & & $\begin{array}{l}0.348^{* * *} \\
(2.03)\end{array}$ & & $\begin{array}{l}-0.041 \\
(0.18)\end{array}$ & & $\begin{array}{l}0.237^{*} \\
(1.82)\end{array}$ & & $\begin{array}{l}-0.091 \\
(0.58)\end{array}$ \\
\hline $\log (1+\mathrm{R} \& \mathrm{D} /$ Asset $)$ & $\begin{array}{l}0.461 * * * \\
(11.19) \\
\end{array}$ & $\begin{array}{l}0.441 * * * \\
(9.65)\end{array}$ & $\begin{array}{l}0.364 * * * \\
(5.79)\end{array}$ & $\begin{array}{l}0.296 * * * \\
(4.30)\end{array}$ & $\begin{array}{l}0.820 * * * \\
(12.39) \\
\end{array}$ & $\begin{array}{l}0.801 * * * \\
(10.76)\end{array}$ & $\begin{array}{l}0.554 * * * \\
(5.81)\end{array}$ & $\begin{array}{l}0.471 * * * \\
(4.43)\end{array}$ & $\begin{array}{l}0.494 * * * \\
(10.98) \\
\end{array}$ & $\begin{array}{l}0.478 \text { *** } \\
(9.42)\end{array}$ & $\begin{array}{l}0.293 * * * \\
(4.72)\end{array}$ & $\begin{array}{l}0.252 * * * \\
(3.66)\end{array}$ \\
\hline Controls & Yes & Yes & Yes & Yes & Yes & Yes & Yes & Yes & Yes & Yes & Yes & Yes \\
\hline Observations & 6055 & 5172 & 2884 & 2590 & 6055 & 5172 & 2884 & 2590 & 6055 & 5172 & 2884 & 2590 \\
\hline Adjusted R-Sq & 0.545 & 0.571 & 0.519 & 0.548 & 0.528 & 0.550 & 0.468 & 0.496 & 0.506 & 0.526 & 0.468 & 0.500 \\
\hline
\end{tabular}




\section{Table 12. Overconfident CEOs and firm value}

The table presents results from regressions Tobin's $Q$ on an industry instrument for firm growth opportunities and on CEO overconfidence. Industry PE, the proxy for growth opportunities, is calculated as the average monthly industry PE over the fiscal year. The monthly industry PE is calculated as the log transformation of the industry's total market capitalization to total earnings less a 60-month moving average. In Panel A, results are shown where CEO overconfidence is measured using either Confident CEO (Options) or Confident CEO (Press). Confident CEO (Options) is an indicator variable that is equal to one for all years after the CEO holds options that are at least 67\% in-the-money. Confident CEO (Press) is equal to one when the number of 'confident' articles for a CEO in Factiva exceeds the number of 'cautious' articles. In Panel B, results are shown where CEOs can have three levels of overconfidence. Confident CEO (Low) is an indicator variable that is equal one for all years after the CEO holds options that are at least $67 \%$ in-the-money but less than $130 \%$ in-the-money, and zero otherwise. Confident CEO (Med) is equal to one for all years after the CEO holds options that are at least $130 \%$ in-the-money but less than $250 \%$ in-the-money, and zero otherwise. Confident CEO (High) is equal to one for all years after the CEO holds options that are at least $250 \%$ in-the-money, and zero otherwise. All independent variables are lagged by one year. All continuous independent variables are scaled to have zero mean and standard deviation of one. Definitions of the variables are described in Appendix A. All regressions include year and industry fixed effects, defined based on 2digit SIC codes. Standard errors are corrected for clustering of observations at the firm level ( $t$-statistics are in parentheses). $*, * *$, and $* * *$ measure significance at the $10 \%, 5 \%$, and $1 \%$ level, respectively.

\section{Panel A. Confident CEO (Options) and Confident CEO (Press)}

\begin{tabular}{|c|c|c|c|c|c|c|c|}
\hline & \multicolumn{7}{|c|}{ Dependent variable $=$ Tobin's $Q$} \\
\hline & \multirow[b]{2}{*}{ (1) } & \multicolumn{2}{|c|}{ Full Sample } & \multicolumn{2}{|c|}{ Innovative Ind. } & \multicolumn{2}{|c|}{ Non-Innovative Ind. } \\
\hline & & $(2)$ & $(3)$ & (4) & $(5)$ & (6) & $(7)$ \\
\hline \multirow[t]{2}{*}{ Industry PE } & $0.056 * * *$ & $-0.042 *$ & -0.015 & $-0.054 *$ & -0.047 & 0.011 & $0.051 *$ \\
\hline & $(3.28)$ & $(1.88)$ & $(0.69)$ & $(1.82)$ & $(1.59)$ & $(0.34)$ & $(1.71)$ \\
\hline \multirow[t]{2}{*}{ Confident CEO (Options) } & & $0.336 * * *$ & & $0.266 * * *$ & & $0.429 * * *$ & \\
\hline & & $(7.15)$ & & $(5.63)$ & & $(4.81)$ & \\
\hline \multirow[t]{2}{*}{ Confident CEO (Options)*Ind. PE } & & $0.067 * * *$ & & $0.067 * *$ & & 0.054 & \\
\hline & & $(2.68)$ & & $(2.23)$ & & $(1.25)$ & \\
\hline \multirow[t]{2}{*}{ Confident CEO (Press) } & & & $0.426^{*}$ & & 0.474 & & 0.276 \\
\hline & & & $(1.84)$ & & $(1.50)$ & & $(1.52)$ \\
\hline \multirow[t]{2}{*}{ Confident CEO (Press)*Ind. PE } & & & 0.147 & & 0.174 & & 0.116 \\
\hline & & & $(1.06)$ & & $(1.11)$ & & $(0.87)$ \\
\hline \multirow[t]{2}{*}{ TotalMention } & & & $0.321 * * *$ & & $0.327 * * *$ & & $0.346 * * *$ \\
\hline & & & $(5.49)$ & & $(4.46)$ & & $(3.95)$ \\
\hline \multirow[t]{2}{*}{ Log(sales) } & & $-0.262 * * *$ & $-0.448 * * *$ & $-0.286 * * *$ & $-0.468 * * *$ & $-0.162 * *$ & $-0.393 * * *$ \\
\hline & & $(6.07)$ & $(7.95)$ & $(5.87)$ & $(7.30)$ & $(2.18)$ & $(3.97)$ \\
\hline \multirow[t]{2}{*}{ Log(PPE/Emp) } & & 0.032 & 0.037 & $0.098^{*}$ & $0.139 * *$ & -0.113 & $-0.186^{* * *}$ \\
\hline & & $(0.70)$ & $(0.77)$ & $(1.71)$ & $(2.20)$ & $(1.60)$ & $(2.76)$ \\
\hline \multirow[t]{2}{*}{ Stock return } & & $0.545 * * *$ & $0.513 * * *$ & $0.619 * * *$ & $0.620 * * *$ & $0.378 * * *$ & $0.292 * * *$ \\
\hline & & $(6.98)$ & $(6.24)$ & $(5.57)$ & $(5.13)$ & $(6.41)$ & $(7.10)$ \\
\hline \multirow[t]{2}{*}{ Stock return*Ind. PE } & & $-0.073 * *$ & $-0.101 * * *$ & $-0.115^{* *}$ & $-0.163 * * *$ & 0.006 & -0.016 \\
\hline & & $(2.00)$ & $(2.82)$ & $(2.28)$ & (3.04) & $(0.16)$ & $(0.51)$ \\
\hline \multirow[t]{2}{*}{ ROA } & & $0.226 * * *$ & $0.365 * * *$ & $0.293 * * *$ & $0.388 * * *$ & 0.079 & $0.306^{* *}$ \\
\hline & & $(3.68)$ & $(5.41)$ & $(4.36)$ & $(5.46)$ & $(0.69)$ & $(2.26)$ \\
\hline \multirow[t]{2}{*}{ \# segments } & & $-0.126 * * *$ & $-0.123 * * *$ & $-0.112 * * *$ & $-0.122 * * *$ & $-0.138 * * *$ & $-0.104 * *$ \\
\hline & & $(3.91)$ & $(3.77)$ & $(2.75)$ & $(3.06)$ & $(2.83)$ & $(2.05)$ \\
\hline Observations & 8907 & 8114 & 7040 & 5435 & 4630 & 2679 & 2410 \\
\hline Adjusted $R$-Sq & 0.112 & 0.205 & 0.216 & 0.197 & 0.211 & 0.240 & 0.255 \\
\hline
\end{tabular}


Panel B. Different degrees of overconfidence

\begin{tabular}{|c|c|c|c|}
\hline & \multicolumn{3}{|c|}{ Dependent variable $=$ Tobin's $\mathrm{Q}$} \\
\hline & $\begin{array}{l}\text { Full Sample } \\
\text { (1) }\end{array}$ & $\begin{array}{l}\text { Innovative Ind. } \\
\text { (2) }\end{array}$ & $\begin{array}{l}\text { Non-Innovative } \\
\text { Ind. } \\
\text { (3) }\end{array}$ \\
\hline Industry PE & $\begin{array}{l}-0.047 * * \\
(2.14)\end{array}$ & $\begin{array}{l}-0.062 * * \\
(2.11)\end{array}$ & $\begin{array}{l}0.007 \\
(0.22)\end{array}$ \\
\hline Confident CEO (Low)*Ind. PE & $\begin{array}{l}0.024 \\
(0.73)\end{array}$ & $\begin{array}{l}0.028 \\
(0.67)\end{array}$ & $\begin{array}{l}0.006 \\
(0.14)\end{array}$ \\
\hline Confident CEO (Med)*Ind. PE & $\begin{array}{l}0.052 \\
(1.51)\end{array}$ & $\begin{array}{l}0.062 \\
(1.55)\end{array}$ & $\begin{array}{l}0.049 \\
(0.69)\end{array}$ \\
\hline Confident CEO (High)*Ind. PE & $\begin{array}{l}0.137 * * * \\
(2.72)\end{array}$ & $\begin{array}{l}0.134 * * \\
(2.16)\end{array}$ & $\begin{array}{l}0.132 \\
(1.55)\end{array}$ \\
\hline Confident CEO (Low) & $\begin{array}{l}0.106^{*} \\
(1.90)\end{array}$ & $\begin{array}{l}0.059 \\
(0.85)\end{array}$ & $\begin{array}{l}0.134 * \\
(1.68)\end{array}$ \\
\hline Confident CEO (Med) & $\begin{array}{l}0.187 * * * \\
(2.68)\end{array}$ & $\begin{array}{l}0.032 \\
(0.45)\end{array}$ & $\begin{array}{l}0.456 * * * \\
(3.29)\end{array}$ \\
\hline Confident CEO (High) & $\begin{array}{l}0.738 * * * \\
(7.87)\end{array}$ & $\begin{array}{l}0.683 * * * \\
(6.48)\end{array}$ & $\begin{array}{l}0.795^{* * * *} \\
(4.86)\end{array}$ \\
\hline $\log ($ sales $)$ & $\begin{array}{l}-0.240 * * * \\
(5.58)\end{array}$ & $\begin{array}{l}-0.268 * * * \\
(5.56)\end{array}$ & $\begin{array}{l}-0.132^{*} \\
(1.76)\end{array}$ \\
\hline Log(PPE/Emp) & $\begin{array}{l}0.030 \\
(0.67)\end{array}$ & $\begin{array}{l}0.098^{*} \\
(1.73)\end{array}$ & $\begin{array}{l}-0.119^{*} \\
(1.68)\end{array}$ \\
\hline Stock return & $\begin{array}{l}0.526 * * * \\
(6.84)\end{array}$ & $\begin{array}{l}0.597 * * * \\
(5.46)\end{array}$ & $\begin{array}{l}0.363 * * * \\
(6.34)\end{array}$ \\
\hline Stock return*Ind. PE & $\begin{array}{l}-0.086^{* *} \\
(2.40)\end{array}$ & $\begin{array}{l}-0.132 * * * \\
(2.65)\end{array}$ & $\begin{array}{l}-0.000 \\
(0.01)\end{array}$ \\
\hline ROA & $\begin{array}{l}0.218 * * * \\
(3.58)\end{array}$ & $\begin{array}{l}0.287 * * * \\
(4.30)\end{array}$ & $\begin{array}{l}0.070 \\
(0.62)\end{array}$ \\
\hline \# segments & $\begin{array}{l}-0.120 * * * \\
(3.81)\end{array}$ & $\begin{array}{l}-0.104 * * * \\
(2.63)\end{array}$ & $\begin{array}{l}-0.135 * * * \\
(2.79)\end{array}$ \\
\hline Observations & 8114 & 5435 & 2679 \\
\hline Adjusted $R-\mathrm{Sq}$ & 0.214 & 0.207 & 0.251 \\
\hline
\end{tabular}

